\title{
The Effectiveness of Al-Si Coatings for Preventing Interfacial Reaction in Al-Mg Dissimilar Metal Welding
}

\begin{abstract}
YIN WANG, BASEM AL-ZUBAIDY, and PHILIP B. PRANGNELL (D)
The dissimilar welding of aluminum to magnesium is challenging because of the rapid formation of brittle intermetallic compounds (IMC) at the weld interface. An Al-Si coating interlayer was selected to address this problem, based on thermodynamic calculations which predicted that silicon would change the reaction path to avoid formation of the normally observed binary Al-Mg IMC phases $\left(\beta-\mathrm{Al}_{3} \mathrm{Mg}_{2}\right.$ and $\left.\gamma-\mathrm{Al}_{12} \mathrm{Mg}_{17}\right)$. Long-term static heat treatments confirmed that a Si-rich coating will preferentially produce the $\mathrm{Mg}_{2} \mathrm{Si}$ phase in competition with the less stable, $\beta-\mathrm{Al}_{3} \mathrm{Mg}_{2}$ and $\gamma-\mathrm{Al}_{12} \mathrm{Mg}_{17}$ binary IMC phases, and this reduced the overall reaction layer thickness. However, when an Al-Si clad sheet was tested in a real welding scenario, using the Refill $^{T \mathrm{TM}}$ friction stir spot welding (FSSW) technique, $\mathrm{Mg}_{2} \mathrm{Si}$ was only produced in very small amounts owing to the much shorter reaction time. Surprisingly, the coating still led to a significant reduction in the IMC reaction layer thickness and the welds exhibited enhanced mechanical performance, with improved strength and fracture energy. This beneficial behavior has been attributed to the softer coating material both reducing the welding temperature and giving rise to the incorporation of $\mathrm{Si}$ particles into the reaction layer, which toughened the brittle interfacial IMC phases during crack propagation.
\end{abstract}

https://doi.org/10.1007/s11661-017-4341-1

(C) The Author(s) 2017. This article is an open access publication

\section{INTRODUCTION}

Aluminum (Al) and Magnesium $(\mathrm{Mg})$ alloys are regarded as ideal candidates for the next generation of more fuel efficient vehicles, because of their low density and high recyclability. ${ }^{[1,2]}$ This high potential for automotive applications has aroused wide interest in joining $\mathrm{Al}$ and $\mathrm{Mg}$ components. However, the metallurgical joining of $\mathrm{Al}$ and $\mathrm{Mg}$ alloys is very challenging, even when employing solid-state welding techniques such as friction stir welding (FSW) ${ }^{[3-8]}$ This is primarily because the rapid formation of $\mathrm{Al}-\mathrm{Mg}$ intermetallic compounds (IMCs) at the weld interface leads to severe embrittlement. ${ }^{[3,6-9]}$ In dissimilar welding and diffusion bonding, an IMC layer comprised the FCC $\beta-\mathrm{Al}_{3} \mathrm{Mg}_{2}$ and $\mathrm{BCC}$ $\gamma-\mathrm{Al}_{12} \mathrm{Mg}_{17}$ phases is normally seen to form at the joint interface. ${ }^{[4-7,9,10]}$ The rapid growth of this reaction layer is intrinsically linked to the high diffusion rates of $\mathrm{Al}$

YIN WANG, BASEM AL-ZUBAIDY, and PHILIP B. PRANGNELL are with the School of Materials, Manchester University, Manchester, M139PL, UK. Contact e-mail: Philip. prangnell@manchester.ac.uk; URL: https://www.research.manches ter.ac.uk/portal/philip.prangnell.html

The original version of this article was revised due to a retrospective Open Access order.

Manuscript submitted April 11, 2017.

Article published online October 11, 2017 and $\mathrm{Mg}$ solute, both in each other as a parent solid solution phase and through the Al-Mg IMC phases themselves, when present as a continuous barrier layer at the weld interface. ${ }^{[11,12]}$

Of the IMC phases present in the binary Al-Mg system, $\beta-\mathrm{Al}_{3} \mathrm{Mg}_{2}$ (the so called 'Samson phase') ${ }^{[13]}$ is regarded as most detrimental to weld performance because: (i) it has the highest growth rate ${ }^{[4,9-11]}$ and (ii) has the lowest toughness, ${ }^{[9]}$ and thus provides a preferential crack propagation path along the joint interface. ${ }^{[9,14]}$ It would therefore be beneficial to implement measures for controlling the extent of IMC reaction in $\mathrm{Al}-\mathrm{Mg}$ welds and, in particular, to inhibit the production of the $\beta-\mathrm{Al}_{3} \mathrm{Mg}_{2}$ phase.

Two metallurgical approaches could be adopted to achieve this goal. Firstly, a diffusion barrier layer could be employed to physically separate the parent alloys and prevent Al-Mg inter-diffusion. Secondly, by altering the alloy composition, the reaction path could be changed to preferentially form a new phase with a higher stability that has a lower growth rate and better mechanical performance, thereby reducing the thickness of the intermetallic layer and improving its fracture behavior. Both methods could be implemented by applying an appropriate interlayer, in the form of a coating, on the surface of one of the parent alloys. Some success has already been found by other authors who have investigated the potential of various interlayer materials, including $\mathrm{Mn}$ and $\mathrm{Zn}$ alloys, for improving the dissimilar welding of $\mathrm{Mg}$ to $\mathrm{Al} .{ }^{[15-19]}$ 
However, the properties and thickness of an interlayer-coating material must also be taken into consideration. For example, previous research that employed a manganese barrier layer produced by physical vapor deposition (PVD) found that thin brittle coatings tended to break up during friction welding, compromising their effectiveness. ${ }^{[15]}$

In this investigation, a potential solution has been examined that combines both the above approaches for controlling the interfacial reaction normally seen in $\mathrm{Al}$ to $\mathrm{Mg}$ dissimilar welding. Based on thermodynamic considerations (e.g., Reference 20), a ductile Al-Si coating material has been selected to (i) function as a partial diffusion barrier layer, and (ii) preferentially form a new IMC phase that can suppress the formation of the highly brittle $\mathrm{Al}-\mathrm{Mg}$ intermetallic compounds normally seen at the joint interface.

The effectiveness of the coating has been examined under both isothermal heat treatment and friction stir spot welding (FSSW) conditions, using the Refill ${ }^{\mathrm{TM}}{ }^{[21]}$ welding technique. In addition, the intermetallic products formed at the weld interface, with and without the coating layer, have been fully characterized by electron microscopy. The resultant improvement seen in the welds' mechanical properties has also been determined from lap shear tests and the mechanisms involved are discussed.

\section{EXPERIMENTAL}

All the materials used in the experiments were obtained in the form of 1-mm-thick rolled sheets. A commercial Al-Si clad brazing sheet (denoted as $\mathrm{Al}(\mathrm{Si})$ ) was selected to test the concept of using an Al-Si alloy coating interlayer to improve the joint performance in $\mathrm{Al}-\mathrm{Mg}$ dissimilar welds. This material (designated $\mathrm{Al}(\mathrm{Si})$ ) was manufactured by the "Novelis Fusion" dual-launder DC co-casting process ${ }^{[22]}$ and had an AA6016 core with an AA4045 (10 pct Si) cladding layer. A further unclad 6XXX series Al alloy, AA6111 (in a T4 temper), was used to prepare $\mathrm{Al}-\mathrm{Mg}$ baseline samples for comparison purposes. In all cases, a common automotive alloy, AZ31, was adopted as the $\mathrm{Mg}$ weld member. The compositions of all the materials employed are provided in Table I.

To compare the IMC interface reaction behavior under controlled conditions, samples were prepared for isothermal inter-diffusion experiments. This involved cutting $30 \mathrm{~mm} \times 30 \mathrm{~mm}$ squares from the 1 -mm-thick sheets and cleaning the surfaces by grinding with 320 -grit $\mathrm{SiC}$ paper, followed by rinsing in ethanol. To obtain intimate surface contact, the different material combinations were first lightly welded together using a
$2 \mathrm{~kW}$ Sonobond ultrasonic spot welder with a very short welding time of 0.2 seconds, before heat treatment at $673 \mathrm{~K}\left(400{ }^{\circ} \mathrm{C}\right)$, under argon, for increasing times up to 24 hours. This led to a minimal level of initial reaction with a thin (less than $2 \mu$ m thick) discontinuous intermetallic layer already present. ${ }^{[9]}$ The samples were subsequently heat treated isothermally for times up to 100 hours $673 \mathrm{~K}\left(400{ }^{\circ} \mathrm{C}\right)$ to study the growth behavior and kinetics of the IMC phases produced.

For the welding experiments, the base materials were cut into $25 \mathrm{~mm} \times 100 \mathrm{~mm}$ weld coupons and prepared using the same surface cleaning procedure described above. Spot welds were produced at the center of a 25-mm overlap between the different materials using the Refill $^{\mathrm{TM}}$ friction welding technique, with a HarmsWende ${ }^{\mathrm{GmbH}}$ RPS100, machine. Standard welding parameters were adopted that had previously been optimized by the current authors for dissimilar welding of $\mathrm{Al}-\mathrm{Mg} .{ }^{[23,24]}$ This involved using the shoulder first plunge sequence, with a rotation rate of $2000 \mathrm{rpm}$ and a welding duration of 1 seconds. During welding, the $\mathrm{Mg}$ alloy was positioned as the top sheet through which the tool was plunged, while the coated and uncoated Al sheets were used as the bottom weld member. The plunge depth was controlled to be the same as the top sheet thickness $(1 \mathrm{~mm})$, so that the tool would not penetrate through the coating material. Full details can be found in Reference 24.

For microstructural observation, the dissimilar joints were sectioned perpendicular to the rolling direction (RD), in the ND-TD plane (normal and transverse directions) using a thin diamond wheel slow-saw. The cross sections were ground and polished using oil-based diamond paste, finishing with an oxide particle suspension (OPS), before metallographic examination. For some samples a further step was applied of broad ion beam milling using a Gatan Illion II System, to obtain a strain-free surface for high-resolution EBSD characterization. BSE imaging and EBSD mapping were carried out in an FEI Magellan HR FEG-SEM. TEM samples were prepared by focused ion beam milling with an FEI Quanta FIB and analyzed in an FEI Tecnai G2 30 TEM equipped with an EDX detector. The thickness of the reaction layers was measured by image analysis from the area of each phase divided by the interface length in the image. Multiple images $(\sim 10)$ and different positions were used across each joint interface to obtain an average measurement. This was particularly important in the friction stir spot welds where the reaction layer was not uniform in thickness, owing to the greater rate of heat generation under the tool sleeve.

Tensile tests of the substrate materials and lap shear tests of the dissimilar weld samples were conducted at a

Table I. Nominal Compositions of the Al and Mg Alloys (Weight Percent) Employed in this Study

\begin{tabular}{lllllllllll}
\hline & $\mathrm{Si}$ & $\mathrm{Zn}$ & $\mathrm{Fe}$ & $\mathrm{Cu}$ & $\mathrm{Mn}$ & $\mathrm{Ti}$ & $\mathrm{Cr}$ & $\mathrm{Ni}$ & $\mathrm{Mg}$ \\
\hline AA6016 & 1 to 1.5 & 0.2 & 0.5 & 0.2 & 0.2 & 0.15 & 0.1 & - & 0.25 to 0.6 & balance \\
AA4045 & 9.88 & - & 0.15 & - & - & 0.02 & - & - & - & balance \\
AA6111 & 0.63 & - & 0.05 & 0.75 & 0.05 & 0.06 & 0.06 & - & 0.75 \\
AZ31 & 0.017 & 1.03 & 0.0045 & 0.0036 & 0.2 & - & - & 0.0003 & balance & 2.51 \\
\hline
\end{tabular}


loading rate of $1 \mathrm{~mm} / \mathrm{min}$, using a $50 \mathrm{kN}$ Instron. The interface temperatures reached during FSSW were measured with $0.5-\mathrm{mm} \mathrm{k}$-type thermocouples positioned in a matching $0.5-\mathrm{mm}$ groove, machined in the surface of the Al sheet and placed directly under the sleeve plunge position.

\section{RESULTS AND DISCUSSION}

\section{A. Selection of the Coating Material}

Following thermodynamic assessment of alternative IMC phases to those in the Al-Mg binary system, an $\mathrm{Al}-\mathrm{Si}$ interlayer material was identified as having potential for controlling interface reaction in Al-Mg dissimilar welding for four main reasons. Firstly, as discussed below, $\mathrm{Si}$ is predicted to react with $\mathrm{Mg}$ to form the thermodynamically more stable compound- $\mathrm{Mg}_{2} \mathrm{Si}$, which should substitute for the Al-Mg binary $\beta-\mathrm{Al}_{3} \mathrm{Mg}_{2}$ and $\mathrm{BCC} \gamma-\mathrm{Al}_{12} \mathrm{Mg}_{17}$ phases. ${ }^{[20]}$ Secondly, pure $\mathrm{Al}$ and $\mathrm{Si}$ form a eutectic system in which no intermetallic phases exist and the solubility of $\mathrm{Si}$ in $\mathrm{Al}$ is low (maximum $1.5 \mathrm{wt} \mathrm{pct})^{[25]}$; as a result, excessive $\mathrm{Si}$ is present in the Al matrix as elemental particles. Given that $\mathrm{Al}$ diffusivity in $\mathrm{Si}$ is substantially lower than in $\mathrm{Mg}$ $\left(D_{\mathrm{mg}} \sim 10^{-16} \mathrm{~m}^{2} / \mathrm{s}^{[26]}\right.$ vs $D_{\mathrm{Si}} \sim 10^{-9}$ to $10^{-11} \mathrm{~m}^{2} / \mathrm{s}^{[27]}$ at the peak welding temperatures typically seen in FSSW of $\mathrm{Al}$ to $\mathrm{Mg}$ at $\left[673 \mathrm{~K}\left(400{ }^{\circ} \mathrm{C}\right)\right]$, the $\mathrm{Si}$ phase can also function as a discontinuous diffusion barrier and retard $\mathrm{Al}-\mathrm{Mg}$ inter-diffusion. In addition, Al-Si alloys have good ductility, which is essential for maintaining a continuous interlayer during FSSW and silicon is widely used in Al alloys and can be added in considerable concentrations by casting, which is convenient for manufacturing a coating material.

Figure 1 compares the binary Al-Mg phase diagram to an isopleth at $10 \mathrm{wt}$ pet $\mathrm{Si}$ in the ternary $\mathrm{Al}-\mathrm{Mg}-\mathrm{Si}$ system, calculated using the PANDAT ${ }^{\mathrm{TM}}$ thermodynamic software package with the aluminum database A12012. It can be seen that $\mathrm{Si}$ is expected to have a limited direct effect on the Al-Mg binary phase reactions (including their stability, and reaction temperatures, etc.,) as in the composition range of interest it is not predicted to form any ternary compounds. However, $\mathrm{Mg}_{2} \mathrm{Si}$ is predicted to coexist with other $\mathrm{Al}-\mathrm{Mg}$ phases over a wide composition range (from about 20 to 90 wt pet $\mathrm{Mg}$ ) at both low and elevated temperatures. By calculating the Gibbs free energies of formation for all the IMC phases (shown in Figure 1(b)), it is clear that $\mathrm{Mg}_{2} \mathrm{Si}$ is thermodynamically much more stable than both $\mathrm{Al}_{3} \mathrm{Mg}_{2}$ and $\mathrm{Al}_{12} \mathrm{Mg}_{17},{ }^{[20]}$ with approximately a 30 pct lower Gibbs free energy of formation (Figure 1(c)). These predictions therefore suggest that if an Al-Si interlayer coating is used, the $\mathrm{Mg}_{2} \mathrm{Si}$ phase has a strong tendency to form in preference to the binary Al-Mg phases normally seen during dissimilar welding.

In addition, it is worth noting that $\mathrm{Mg}_{2} \mathrm{Si}$ has superior mechanical properties to the Al-Mg binary IMC phases. For example, $\mathrm{Mg}_{2} \mathrm{Si}$ has previously been synthesized as a reinforcing phase in metal matrix composites. ${ }^{[28]}$ Compared to the binary Al-Mg IMCs normally produced in welding, $\mathrm{Mg}_{2} \mathrm{Si}$ also exhibits overall better physical properties including a higher melting point and greater elastic moduli ${ }^{[29-41]}$ (Table II), which reflects stronger interatomic bonding between $\mathrm{Mg}$ and $\mathrm{Si}$ relative to $\mathrm{Al}$ and $\mathrm{Mg}$. The substitution of $\mathrm{Mg}_{2} \mathrm{Si}$ for $\mathrm{Al}_{3} \mathrm{Mg}_{2}$ and $\mathrm{Al}_{12} \mathrm{Mg}_{17}$ may therefore also be expected to improve the poor resistance to crack propagation through the IMC interfacial layer seen in Al-Mg dissimilar welds. ${ }^{[6,9,14]}$

\section{B. Characterization of the Al-Si Clad Sheet}

The Al-Si coated material selected for this study was a commercial Al-Si clad brazing sheet (Table I). As shown in Figure 2, the clad layer was about $100 \mu \mathrm{m}$ in thickness. The Al-Si cladding also had a relatively sharp interface with the core alloy and contained a uniform distribution of 2 to $5 \mu \mathrm{m}$ diameter broken-up and spheroidized eutectic Si particles, with some smaller Si particles present in the matrix.

\section{Static Diffusion Experiments}

1. Characterization of the interfacial reaction products

In Figure 3, the extent of IMC reaction seen in the clad Al(Si)-AZ31 Mg sample is compared to that of the uncoated AA6111 Al-Mg baseline, after a prolonged isothermal heat treatment of $673 \mathrm{~K}\left(400^{\circ} \mathrm{C}\right)$ for 24 hours. From this figure, it is immediately apparent that in the sample prepared with the $\mathrm{Al}(\mathrm{Si})$ clad sheet the total IMC reaction layer was about half as thick as that seen for the conventional uncoated Al sample. In addition, in the sample prepared with the unclad sheet, the interface region exhibited a continuous and uniformly thick IMC layer comprised of two well-defined sublayers. In contrast, as well as being about 50 pct thinner, the interfacial reaction layer in the $\mathrm{Al}(\mathrm{Si})$ clad sample was more complex and contained an additional phase consisting of irregular-shaped dark particles, embedded within the IMC matrix phase (Figure 3(c)). These particles were aligned normal to the interface, suggesting a tendency to grow parallel to the Al-Mg inter-diffusion direction (Figure 3(c)).

Microanalysis (EDX) and diffraction techniques (EBSD, EDX, and TEM) were used to identify the phases present in each IMC reaction layer. By using EBSD phase identification (Figure 3(b)), in the AA6111 Al-Mg baseline sample, the two sublayers in the interfacial reaction layer were indexed to be $\mathrm{Al}_{12} \mathrm{Mg}_{17}$ and $\mathrm{Al}_{3} \mathrm{Mg}_{2}$. The $\mathrm{Al}_{3} \mathrm{Mg}_{2} \beta$-phase was situated on the $\mathrm{Al}$ side of the interface and formed the thicker, more dominant, IMC layer. This is consistent with previous observations $^{[9-11]}$ where in similar binary Al-Mg diffusion couple experiments the $\beta$ phase has been reported to have a higher growth rate, but forms after the $\gamma$ phase and grows by consuming $\gamma$ as well as growing into the $\mathrm{Al}$ substrate. ${ }^{[9,10]}$

From higher magnification EBSD analysis of the region shown in Figure 3(c) (white rectangle) it can be seen that the interface in the $\mathrm{Al}(\mathrm{Si})-\mathrm{Mg}$ samples also consisted of two Al-Mg IMC layers (although this is not as apparent in the SEM image) with irregular second 


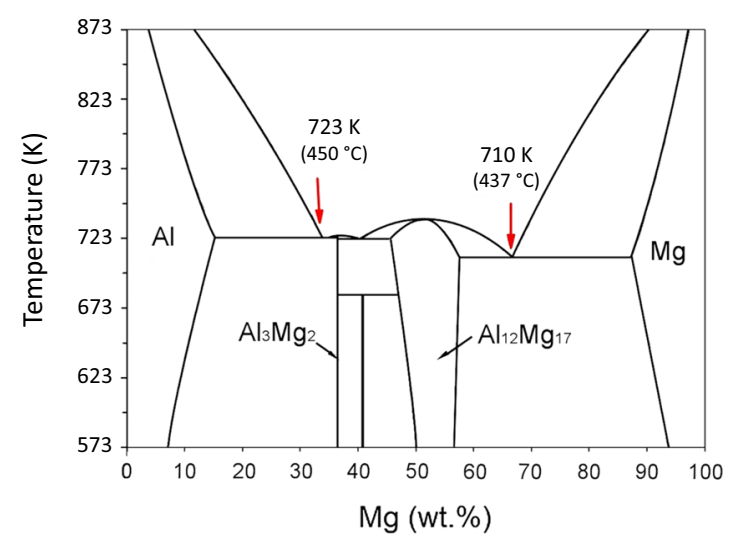

(a)

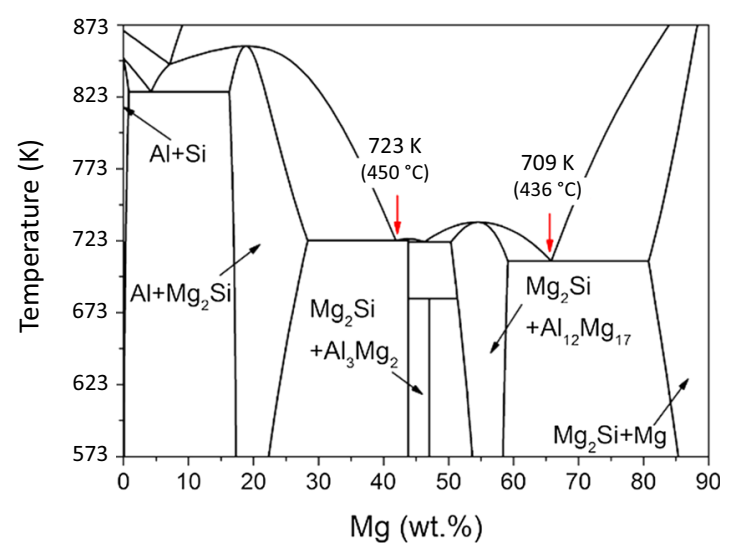

(b)

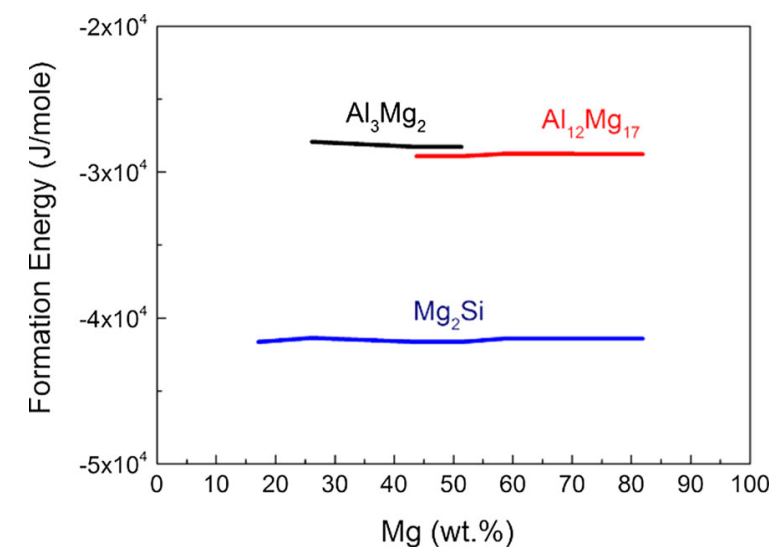

(c)

Fig. 1-Thermodynamic calculations showing: $(a)$ the Al-Mg binary phase diagram; $(b)$ an Al-Mg-Si ternary isopleth at Al-Mg-10 wt pct Si; and (c) comparison of the Gibbs free energies of formation of the Al-Mg and $\mathrm{Mg}-\mathrm{Si} \mathrm{IMCs}$ in an $\mathrm{Al}-\mathrm{Mg}-10$ wt pct $\mathrm{Si}$ alloy, as a function of $\mathrm{Mg}$ content.

Table II. Summary of the Physical Properties of the $\mathrm{Al}_{3} \mathrm{Mg}_{2}, \mathrm{Al}_{12} \mathrm{Mg}_{17}$, and $\mathrm{Mg}_{2} \mathrm{Si}$, IMC Phases, Using Published Experimental (exp.) and Calculated (cal.) Results, Where Known

\begin{tabular}{|c|c|c|c|c|c|c|c|}
\hline \multirow[b]{2}{*}{ Phase } & \multirow[b]{2}{*}{ Density $\left(\mathrm{kg} / \mathrm{m}^{3}\right)$} & \multirow[b]{2}{*}{ Melting Point $\left[\mathrm{K}\left({ }^{\circ} \mathrm{C}\right)\right]$} & \multicolumn{2}{|c|}{$\begin{array}{l}\text { Thermal Expansion } \\
\text { Coefficient }\left(10^{-6} \mathrm{~K}^{-1}\right)\end{array}$} & \multirow[b]{2}{*}{ Vickers Hardness (GPa) } & \multicolumn{2}{|c|}{$\begin{array}{l}\text { Elastic Modulus } \\
\quad(\mathrm{GPa})\end{array}$} \\
\hline & & & Cal. & Exp. & & Cal. & Exp. \\
\hline $\mathrm{Al}_{3} \mathrm{Mg}_{2}$ & $2.25 \times 10^{-3[30]}$ & {$[723(450)]^{[20]}$} & & 22.1 to $23.4^{[29]}$ & $3.5^{[10]}$ & & $\begin{array}{l}60^{[10]} \\
50^{[31]}\end{array}$ \\
\hline $\mathrm{Al}_{12} \mathrm{Mg}_{17}$ & $2.09^{[32]}$ & {$[710(437)]^{[20]}$} & $23.9^{[33]}$ & & $\begin{array}{l}3.3^{[10]} \\
2.5^{[34]}\end{array}$ & $78^{[33]}$ & $70^{[10,35]}$ \\
\hline $\mathrm{Mg}_{2} \mathrm{Si}$ & $1.99 \times 10^{-3[36]}$ & {$[1358(1085)]^{[20]}$} & & $7.5^{[37,39]}$ & $4.1^{[40]}$ & $113.5^{[41]}$ & $\begin{array}{l}76^{[40]} \\
120^{[41]}\end{array}$ \\
\hline
\end{tabular}

phase particles being present in the lower sublayer (Figure 3(d)). Similar to in the baseline sample, the (upper) IMC sublayer adjacent to the $\mathrm{Mg}$ sheet was indexed to be the $\gamma-\mathrm{Al}_{12} \mathrm{Mg}_{17}$ binary $\mathrm{Al}-\mathrm{Mg}$ phase and that next to the $\mathrm{Al}$ substrate the $\beta-\mathrm{Al}_{3} \mathrm{Mg}_{2}$ phase. However, EBSD phase identification of the irregular-shaped particles in the lower sublayer was inconclusive as they were indexed to be either $\mathrm{Mg}_{2} \mathrm{Si}$ or $\mathrm{Si}$ (Figure 3(d)).

Higher magnification EDX mapping (Figures 4(a) through (d)) and TEM micro-diffraction analysis
(Figures 4(e) and (f)) confirmed that the irregular second phase particles within the reaction layer in the $\mathrm{Al}(\mathrm{Si})-\mathrm{Mg}$ sample were mainly $\mathrm{Mg}_{2} \mathrm{Si}$, which had been synthesized in situ by reaction between $\mathrm{Mg}$ and the $\mathrm{Si}$ particles dispersed in the cladding alloy. This observation is also supported by the presence of residual $\mathrm{Si}$ found encapsulated in some of the $\mathrm{Mg}_{2} \mathrm{Si}$ particles, shown in the EDX maps in Figure 4(c). Thus, by this stage the $\mathrm{Mg}_{2} \mathrm{Si}$ phase had nucleated on and grown to completely coat the Si particles, which by volume had on average transformed by $\sim 70$ pet to $\mathrm{Mg}_{2} \mathrm{Si}$. Further 


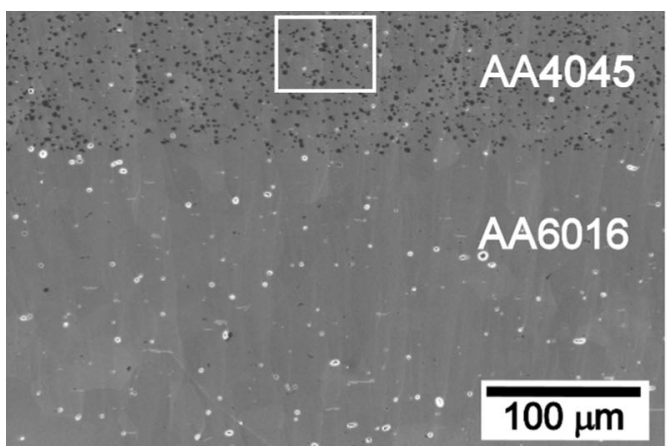

(a)

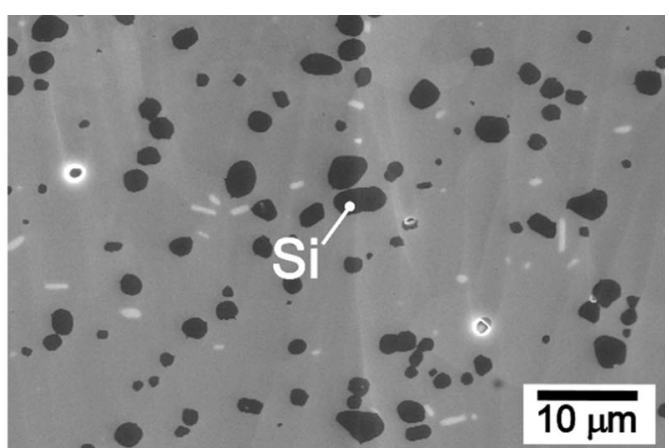

(b)

Fig. 2-SEM Characterization of the 'Novelis Fusion ${ }^{\mathrm{TM}}$ ' brazing sheet; $(a)$ image of the whole cladding layer, $(b)$ the Si particles at a higher magnification.
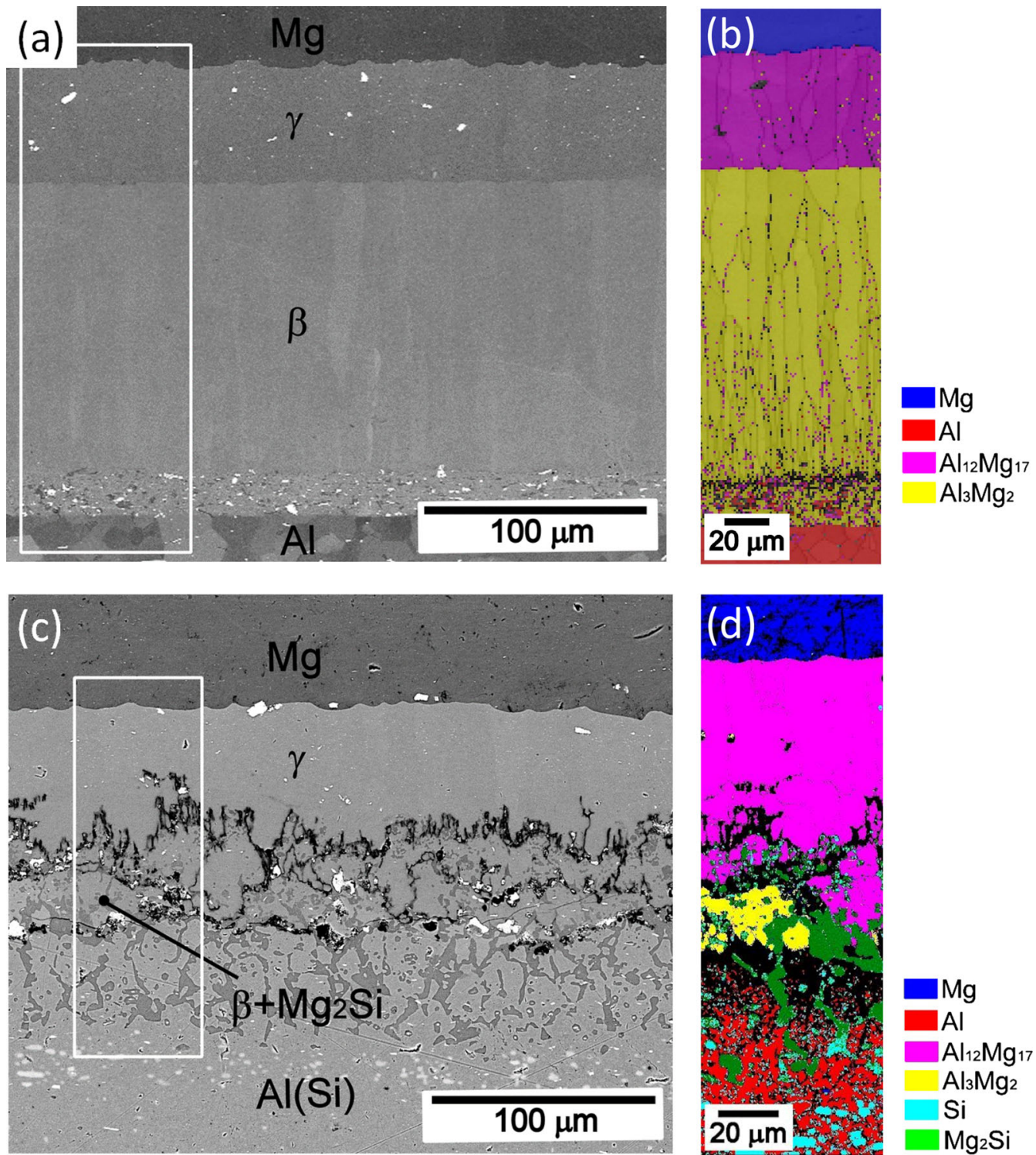

Fig. 3-Interfacial characterization of $(a-b)$ the unclad $\mathrm{Al}$ and $(c-d)$ the $\mathrm{Al}(\mathrm{Si})$ clad-Mg $\mathrm{AZ} 31$ isothermal inter-diffusion samples, after annealing at $673 \mathrm{~K}\left(400^{\circ} \mathrm{C}\right)$ for $24 \mathrm{~h}$; (b) and (d) are EBSD phase maps from the boxed regions shown in (a) and (c), respectively (Color figure online). 

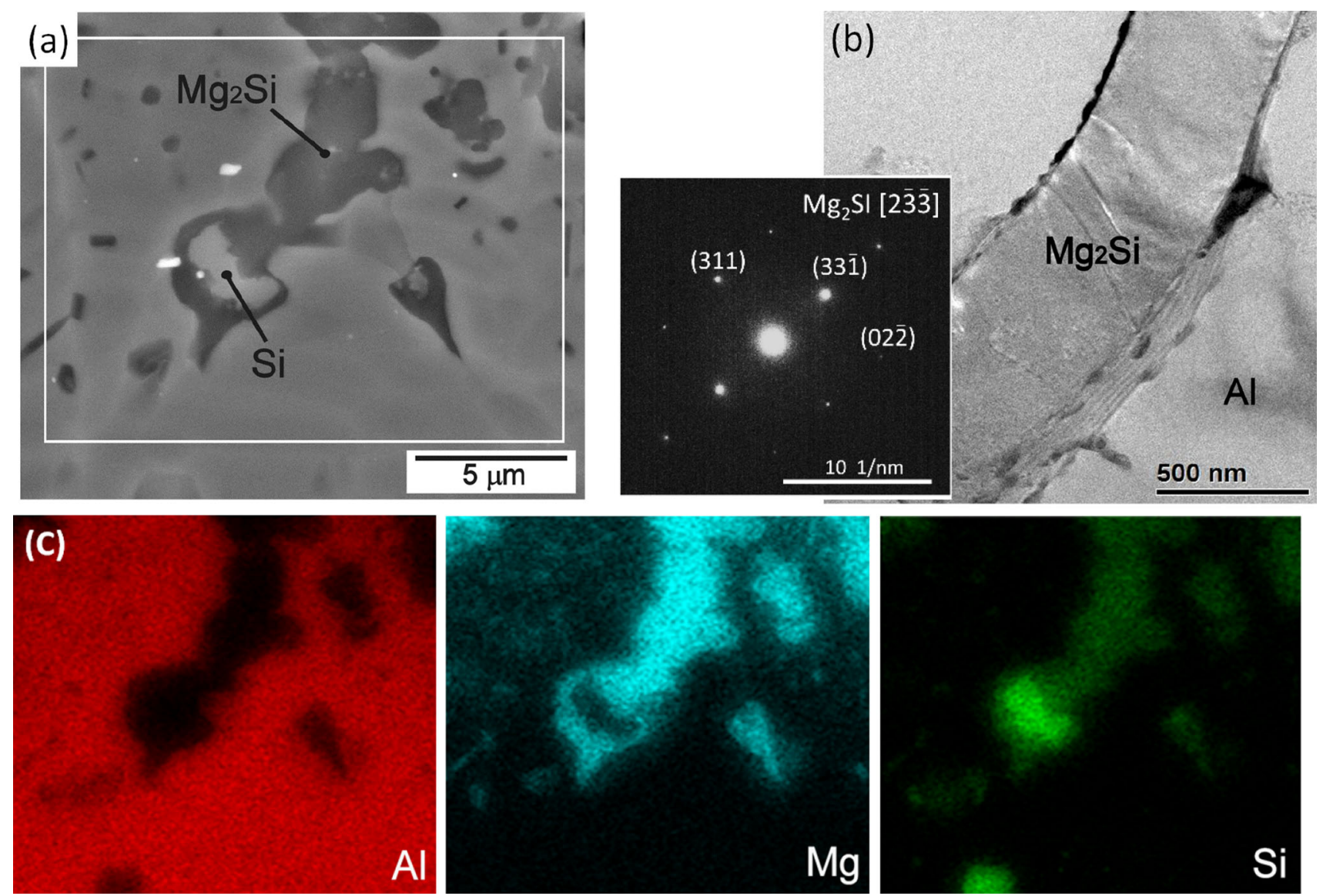

Fig. 4-Phase identification of the second phase particles formed in the interfacial region of the clad $\mathrm{Al}(\mathrm{Si})-\mathrm{Mg}$ joint, after heat treatment at $673 \mathrm{~K}\left(400{ }^{\circ} \mathrm{C}\right)$ for $3 \mathrm{~h}$ : $(a)$ enlarged SEM-BSE micrograph of the white box area in Fig. 3(b), (b) TEM identification of the Mg $\mathrm{Si}_{2}$ second phase in the Al-Si cladding layer, and (c) SEM-EDX maps from the white box area in (a).

growth of the $\mathrm{Mg}_{2} \mathrm{Si}$ phase would therefore involve $\mathrm{Mg}$ diffusing through the thick continuous $\mathrm{Mg}_{2} \mathrm{Si}$ coating on the Si particles to react with Si.

Within the overall reaction layer, the $\mathrm{Mg}_{2} \mathrm{Si}$ particles were mainly found to be located in the lower $\beta-\mathrm{Al}_{3} \mathrm{Mg}_{2}$ phase sublayer, which formed the matrix between the particles (Figure 3). This occurred because the $\beta$ phase grew into the $\mathrm{Al}$ side of the weld, and also consumed the $\gamma$ phase. In comparison, the $\gamma$ phase grew into the $\mathrm{Mg}$ substrate where there were no $\mathrm{Si}$ particles originally present. Consequently, the $\gamma$ phase sublayer did not develop any $\mathrm{Mg}_{2} \mathrm{Si}$ particles because $\mathrm{Si}$ from the original cladding alloy reacted readily with the surrounding $\mathrm{Mg}$ in the $\beta$ phase matrix and was not able to diffuse sufficiently far from the original $\mathrm{Al}$ interface position to react with $\gamma$.

However, some $\mathrm{Mg}_{2} \mathrm{Si}$ particles were found to penetrate slightly in to the Al-Si cladding alloy immediately below the IMC layer to a depth of about $70 \mu \mathrm{m}$ (Figure 4) where there would be expected to be a relatively low $\mathrm{Mg}$ concentration. Overall, these results are therefore in good agreement with the thermodynamic calculations discussed above, which predicted that $\mathrm{Mg}_{2} \mathrm{Si}$ had the lowest Gibbs free energy of formation of all the intermetallic compounds in the
$\mathrm{Al}-\mathrm{Mg}-\mathrm{Si}$ system and can coexist with the Al-Mg binary phases over a wide range of compositions at average $\mathrm{Si}$ concentrations equivalent to that in the cladding alloy (see Figure 1).

\section{Reaction layer growth kinetics}

Further evidence of the effectiveness of the Al-Si coating in retarding the growth rate of the IMC reaction layer, under long-term static conditions, is provided in Figure 5. In this figure the thickening rates of the total reaction layer, and individual $\gamma-\mathrm{Al}_{12} \mathrm{Mg}_{17}$ and $\beta-\mathrm{Al}_{3} \mathrm{Mg}_{2}$ sublayers, are compared between samples produced with coated and uncoated aluminum sheets during extended heat treatment up to 120 hours at $673 \mathrm{~K}\left(400{ }^{\circ} \mathrm{C}\right)$. From Figure 5(b), it can be seen that growth rate of the $\mathrm{Al}_{3} \mathrm{Mg}_{2} \beta$-phase was in particular greatly inhibited by the presence of the Al-Si cladding alloy and exhibited a much slower increase in thickness, whereas the $\mathrm{Al}_{12} \mathrm{Mg}_{17}$ $\gamma$-phase that formed on the $\mathrm{Mg}$ side of the joint (Figure 5(a)) was in fact found to have a slightly higher thickening rate than seen in the control sample. The substantial (approximately $50 \mathrm{pct}$ ) reduction in the overall $\mathrm{Al}-\mathrm{Mg}$ intermetallic layer thickness achieved by the application of the Al-Si coating in Figure 5 can, therefore, mainly be attributed to a reduction in the 


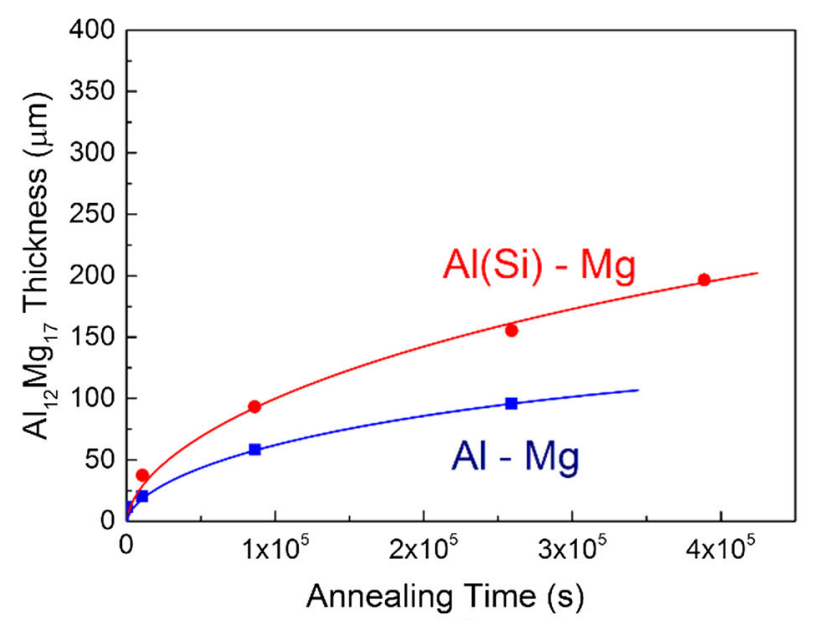

(a)

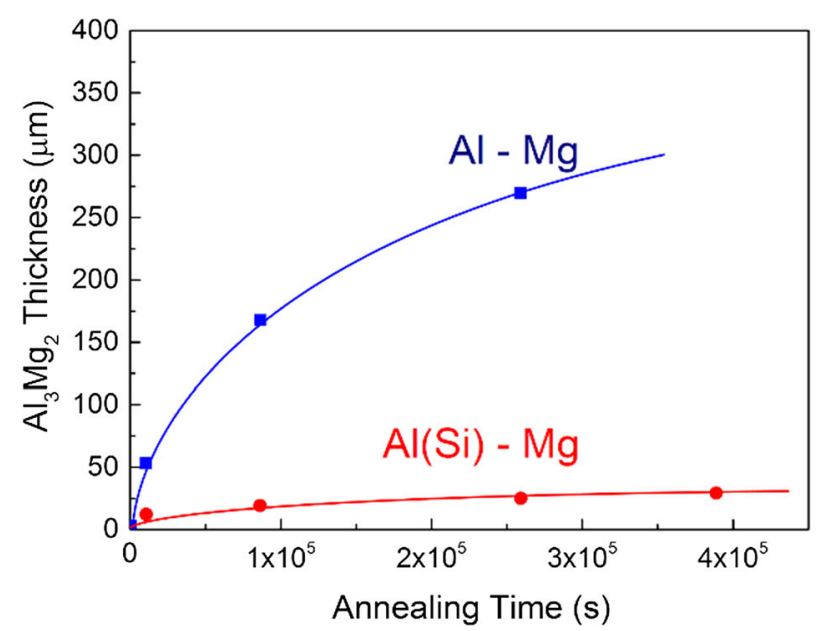

(b)

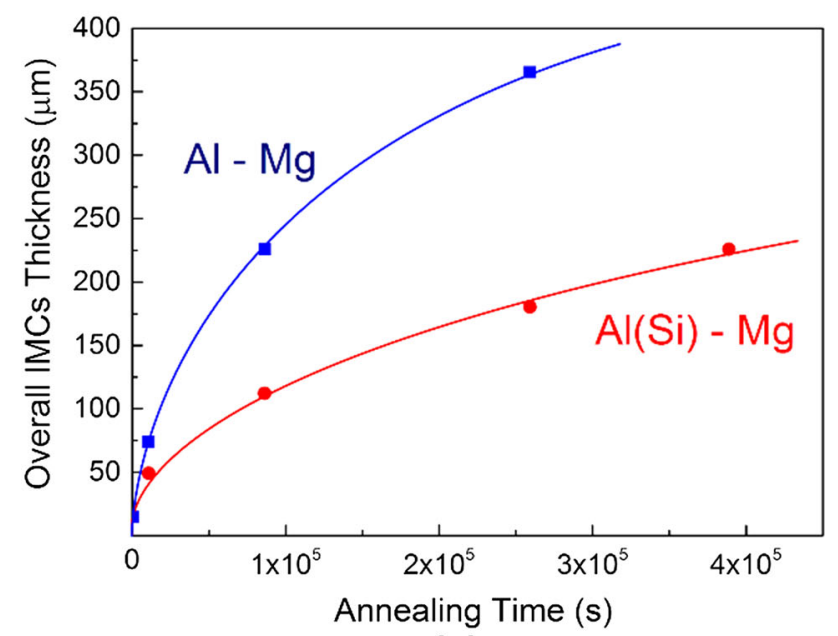

(c)

Fig. 5- Growth rates of (a) the $\mathrm{Al}_{12} \mathrm{Mg}_{17} \gamma$-phase, (b) the $\mathrm{Al}_{3} \mathrm{Mg}_{2}$ $\beta$-phase, and $(c)$ the total IMC layer thickness in the uncoated and coated samples during isothermal annealing at $673 \mathrm{~K}\left(400{ }^{\circ} \mathrm{C}\right)$.

growth rate of the $\beta$ IMC sublayer. The $\beta$ IMC sublayer also grew more slowly into the $\gamma$ phase, which increased its residual thickness (Figure 5(a)).

\section{The Effectiveness of the Al-Si Coating Under Static Conditions}

The above results show that the concept of introducing an $\mathrm{Al}-\mathrm{Si}$ interlayer between $\mathrm{Al}$ and $\mathrm{Mg}$ parent alloys in dissimilar welds has proved successful in reducing the IMC reaction rate during long-term thermal exposure. In particular, the cladding layer has been most effective in inhibiting the development of the $\beta$ phase. The successful behavior of the coating under long-term heat treatment conditions can be explained by two main factors. Firstly, $\mathrm{Mg}$ that diffuses across the interface into the $\mathrm{Al}$ side of the joint reacts preferentially with the $\mathrm{Si}$ present in the cladding layer to form the $\mathrm{Mg}_{2} \mathrm{Si}$ phase. This results in the $\mathrm{Al}_{3} \mathrm{Mg}_{2}-\beta$ phase sublayer being in competition for $\mathrm{Mg}$ solute with the thermodynamically more stable $\mathrm{Mg}_{2} \mathrm{Si}$ phase. Reaction with Si removes $\mathrm{Mg}$ from the matrix, and the growth rate of the $\mathrm{Al}_{3} \mathrm{Mg}_{2}$ phase is consequently greatly reduced (Figure 5(a)). This in turn has significantly affected the overall reaction layer thickness as $\beta$ is the fastest growing phase within the dual phase IMC layer and also reduced its rate of growth in to the $\gamma$ phase.

Secondly, the development of a large local volume fraction of second phase particles that have a low diffusivity for $\mathrm{Al}$ and $\mathrm{Mg}$, have partially blocked $\mathrm{Al}-\mathrm{Mg}$ inter-diffusion by forming a porous barrier layer. In the early stages of the reaction, the particles present were mainly $\mathrm{Si}$, which has near-zero solubility for $\mathrm{Al}$ or $\mathrm{Mg}^{[42]}$ Initially, the Si particles had a relatively low volume fraction (10 pct) and were dispersed in the cladding material; so at the start of the heat treatment their ability to act as a diffusion barrier would be expected to be limited. However, after longer heat treatment times the coarser $\mathrm{Mg}_{2} \mathrm{Si}$ particles that developed started to interconnect. With increasing time, this would progressively form a more impermeable barrier that would help to decrease the rate of $\mathrm{Al}$ and $\mathrm{Mg}$ inter-diffusion and thus also reduce the IMC layer growth rate.

\section{E. FSSW Experiments}

In this study, the Refill ${ }^{\mathrm{TM}}$ friction stir spot welding process was adopted for producing $\mathrm{Al}-\mathrm{Mg}$ dissimilar joints to test the performance of the Al-Si coating alloy in real welds. The welds were completed in a welding cycle of 1 seconds with previously optimized parameters. ${ }^{[23,24]}$ With such a rapid welding cycle, any interfacial reaction will be occurring under highly transient conditions. ${ }^{[43]}$ In addition, high strain-rate deformation near the interface region, where there are typically large shear gradients, can substantially influence any reaction process by intercalating (or 'mixing') the two weld members and breaking up and re-distributing the reaction products. ${ }^{[44,45]}$

\section{Interfacial reaction in FSSW}

Figure 6 provides examples of typical cross sections of the dissimilar Refill ${ }^{\mathrm{TM}}$ FSSW joints produced between the baseline, bare, AA6111 sheet and the $\mathrm{Al}(\mathrm{Si})$ clad 6061 alloy and Mg-AZ31. The sleeve and pin plunge 
areas have been marked on the images and it can be seen that there has been minimal penetration of the tool into the bottom sheet. Both sets of welds with the coated and uncoated Al sheets were produced under identical conditions and importantly, although slightly thinner across the weld area, the Al-Si cladding layer can be observed to still be continuous in the $\mathrm{Al}(\mathrm{Si})-\mathrm{Mg}$ joint (Figure 6(b)).

SEM BSE images of the selected sites (A-D) in the uncoated Al-Mg baseline sample (Figures 7(a) through (d)) show an IMC bi-layer across the majority of the weld interface. Owing to the very short weld cycle, on average, the total IMC layer had a thickness of only about 4.5 to $7 \mu \mathrm{m}$ (Table III). For the unclad samples, the reaction products were identified to consist of a thicker layer of $\mathrm{Al}_{12} \mathrm{Mg}_{17}$, which formed first in the reaction sequence on the $\mathrm{Mg}$ side, and a thinner $\mathrm{Al}_{3} \mathrm{Mg}_{2}$ layer (about $1 \mu \mathrm{m}$ thick) which nucleated on the Al side of the joint. In comparison to the samples prepared by long-term static annealing, the $\beta$ phase was therefore less developed. In addition, there was some evidence of 'mixing' under the sleeve region at the edge of the weld (position $\mathrm{E}$ in Figure 7(a)), which will be discussed further below.

In comparison to the welds produced with the bare Al sheet, the interfacial reaction layer in the clad $\mathrm{Al}(\mathrm{Si})-\mathrm{Mg}$ weld samples was more heterogeneous. In particular, in Figures 7(e) though (h), it can be seen that it contained intercalated layers of different contrast under the sleeve plunge area, and coarse round particles present within the IMC reaction layer of similar size and appearance to the $\mathrm{Si}$ particles seen in the original cladding alloy (Figure 2(b)). Due to its heterogeneity, the overall IMC layer thickness was difficult to measure, but was on average thinner than for the control samples with a range of 3 to $4.5 \mu \mathrm{m}$ (Table III).
To better understand this more complex interface structure, TEM analysis was performed to study the intercalated layers near the edge of the weld and the behavior of the $\mathrm{Si}$ particles (sites $\mathrm{D}$ and $\mathrm{B}$ in Figure 6(b)). Figure 8(a) shows a low-magnification Scanning Transmission Electron Microscope (STEM) image of a sample obtained by FIB milling from a location similar to that in the 'box' indicated in Figure 7(e) which reveals a multi-layer structure distinguished by different crystallite sizes. EDX analysis across the interface (the dashed line in Figure 8(a)) indicates that these layers had a composition corresponding to, either an Al- or Mg-rich solid solution, separated by bands of $\mathrm{Al}-\mathrm{Mg}$ intermetallic phases, as shown in Figure 8(b). TEM SAD patterns (Figure 8(c) through (e)) confirmed that, due to the deformation caused by the tool, the parent materials were 'mixed' at this interface position and during the welding process finely dispersed $\mathrm{Al}-\mathrm{Mg}$ binary IMC phases, were produced between intercalated layers of the $\mathrm{Al}$ and $\mathrm{Mg}$ parent alloys. These IMC particles were mainly identified to be the $\mathrm{Al}_{12} \mathrm{Mg}_{17}$ phase.

With the optimized welding conditions used in this study, the welding tool had a penetration depth of $1 \mathrm{~mm}$, which was approximately the same as the thicknesses of the Mg top sheet. During FSSW, the sleeve and pin thus barely touched the upper surface of the Al sheets. Hence, material flow only occurred very locally in the Al bottom sheet surface, where there would be expected to be a large shear gradient in ND. As a result, mixing between the $\mathrm{Al}$ and $\mathrm{Mg}$ alloys at the sheet surface would be expected to be strongly affected by both the contact conditions and material flow behavior.

The Al-Si cladding alloy employed had a hardness level of only $55 \mathrm{H}_{\mathrm{V}}$, compared to $90 \mathrm{H}_{\mathrm{V}}$ for AA6111 and

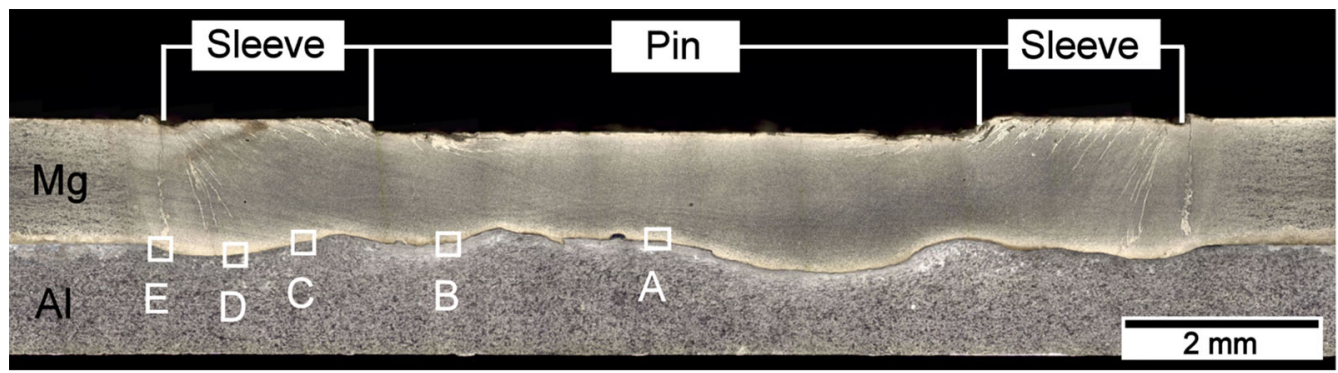

(a)

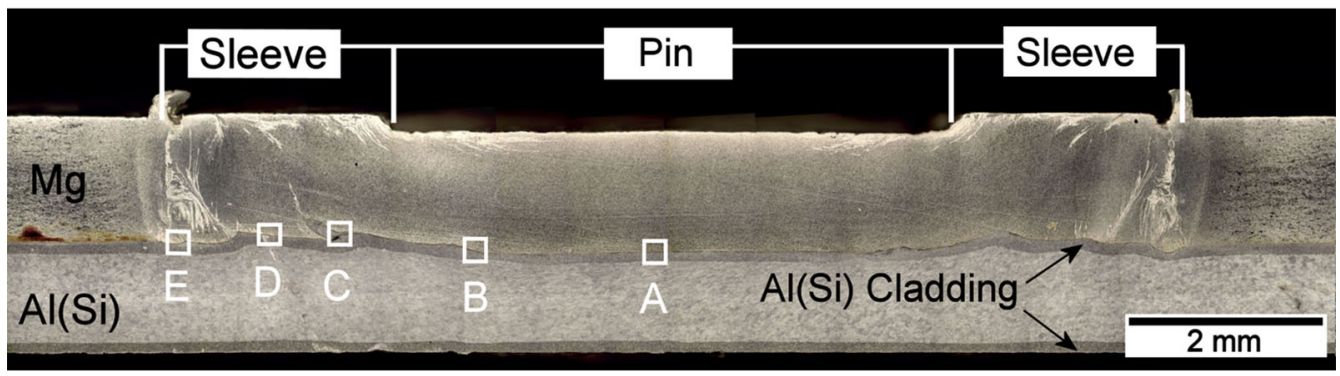

(b)

Fig. 6-Macro view cross sections of the Refill-FSSW welds in; (a) the uncoated Al-Mg baseline and (b) the $\mathrm{Al}(\mathrm{Si})-\mathrm{Mg}$ coated samples. The regions where the weld interfaces have been compared in more detail by electron microscopy are indicated by the boxes A-E. 


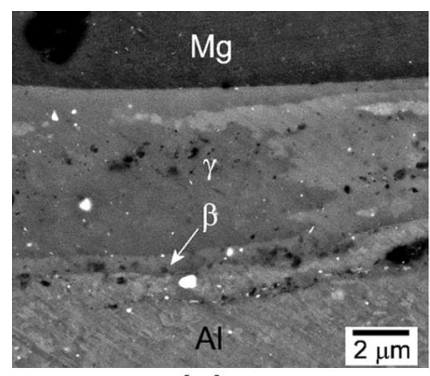

(a)

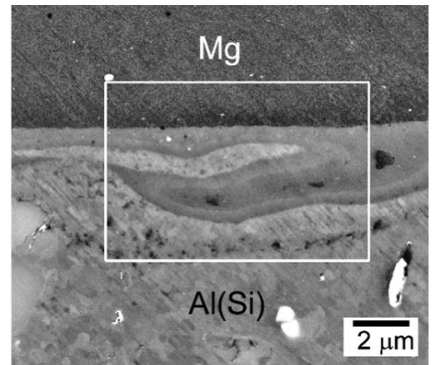

(e)

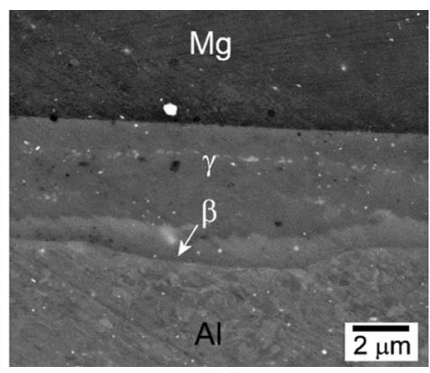

(b)

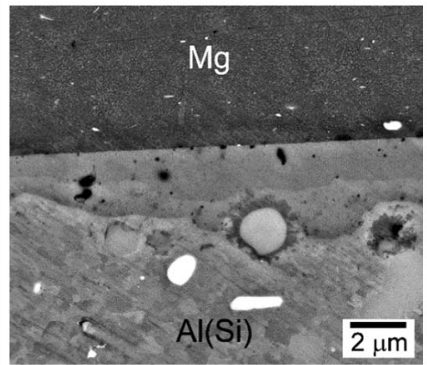

(f)

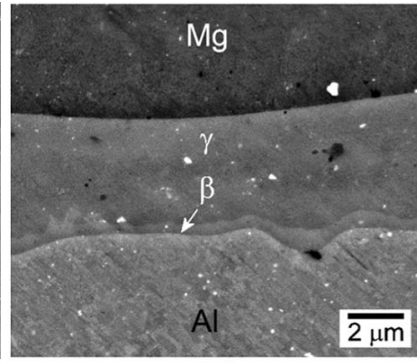

(c)

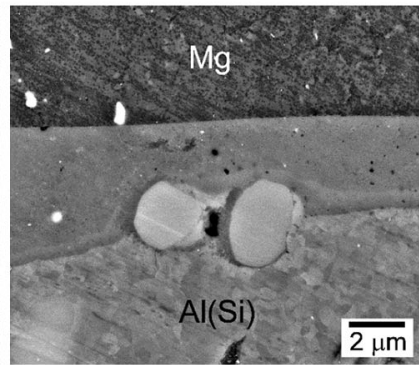

(g)

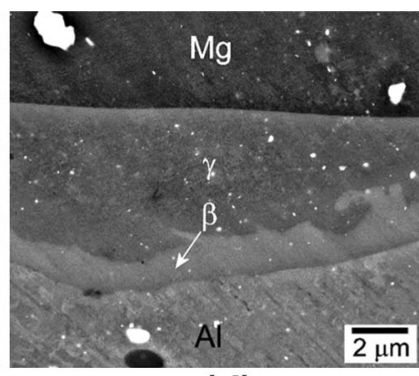

(d)

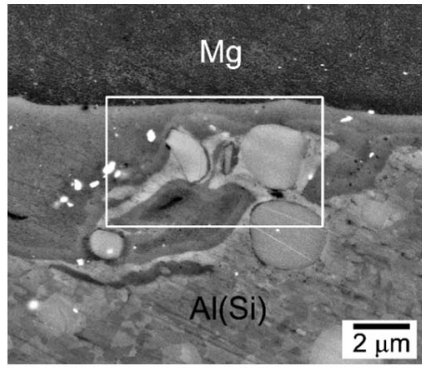

(h)

Fig. 7-SEM-BSE micrographs showing the weld interface of the dissimilar joints produced by the Refill-FSSW process, from the sites indicated in Fig 6; $(a$ through $d)$ positions A-D for the Al-Mg baseline, and ( $e$ through $h)$ positions A-D for the coated Al(Si)-Mg sample, respectively.

Table III. The Average IMC Thickness Measured at Sites A-D in the Conventional and Pre-coated Al-Mg FSS Welds, Respectively, Measured from Fig. 7

Average IMC Layer Thickness (m)

\begin{tabular}{lcccr}
\cline { 2 - 5 } Material & Site A & Site B & Site C & Site D \\
\hline $\mathrm{Al}-\mathrm{Mg}$ & 5.54 & 4.63 & 4.96 & 6.73 \\
$\mathrm{Al}(\mathrm{Si})-\mathrm{Mg}$ & 3.01 & 2.93 & 4.18 & 4.59 \\
\hline
\end{tabular}

$76 \mathrm{HV}$ for the AZ31 alloy. Hence, it was much softer than the AA6111 baseline alloy and, even though identical welding parameters were used, more deformation was induced in the softer surface of the Al-Si coated Al sheet during the tool plunge. This difference in yield strength in the surface layer can thus explain the fact that intercalated layers were mainly observed at the interface of welds produced with the clad Al sheet. (Note: the IMC interphase mixing seen in Figure 7(a) is caused by local melting and will be discussed below). Rapid intermetallic reaction would have taken place at the freshly exposed interfaces between the intercalated $\mathrm{Al}$ and $\mathrm{Mg}$ layers formed during the welding process. However, as this occurred simultaneously with deformation, it resulted in the production of a mechanically dispersed band of fine IMC particles, seen at the interface between each magnesium and aluminum layer in Figure 8(a). Continued reaction would also be expected after deformation during the tool withdrawal stage, which would subsequently cause a non-dispersed, continuous, IMC layer to develop in the final weld.

$\mathrm{Si}$ particles from the cladding layer were transported into the intercalated reaction region by the shearing action of the welding tool, as indicated by the high level of $\mathrm{Si}$ detected from some grains in this area (Figure 8(b)). One such particle, labeled D in Figure 8(a), is shown in more detail in Figure 9; however, TEM analysis gave no evidence for the widespread formation of $\mathrm{Mg}_{2} \mathrm{Si}$. SAD patterns taken from Si-crystallites present at the weld interface (marked with D in Figures 8(a) and 9(a)) indicated that they remained primarily as an elemental $\mathrm{Si}$ particles (Figure 9(b)). Small precipitates of about $100 \mathrm{~nm}$ in size were observed to form at the interface between the $\mathrm{Si}$ grains and the Al matrix, but were too small to fully isolate without employing higher resolution methods. EDX analysis in the TEM measured significant levels of Al, Mg, and Si (Figure 9(e)). These very small particles are thus probably the $\mathrm{Mg}_{2} \mathrm{Si}$ phase, with a background Al signature, but it is also possible that they could be an Al-Mg-Si ternary metastable phase that have been reported to form prior to the $\mathrm{Mg}_{2} \mathrm{Si}$ phase under transient conditions. ${ }^{[46,47]}$ Under friction spot welding conditions, the Si particles were therefore found to only react very locally with $\mathrm{Mg}$ and it can be concluded that $\mathrm{Si}$ had little effect on inhibiting the Al-Mg binary IMC reactions. This low level of local reaction would also not be expected to greatly affect the mechanical properties of the welds. 
The average thicknesses of the reaction layer found at the interface positions in Figure 6 are provided in Table III. For both sample types, the IMC layer tended to be thicker under the sleeve plunge area than at the center of each weld. This is not surprising, as in the Refill FSW process the highest weld temperatures are known to be reached under the sleeve where there is the greatest relative tool surface velocity. ${ }^{[24,44,45,48]}$ However, when compared to the baseline sample, prepared under identical conditions, the $\mathrm{Al}(\mathrm{Si})-\mathrm{Mg}$ joint exhibited an overall reduction of about 30 pct in the thickness of the reaction layer, despite not forming a significant quantity of $\mathrm{Mg}_{2} \mathrm{Si}$. As discussed above, this improvement may be partly related to more mixing occurring with the softer cladding layer, which would be expected lead to greater dispersal of the reaction products, but another important factor to consider is if the same interface temperature was reached for each set of welds.

\section{Weld interface temperatures}

The weld interface temperature is a critical parameter that can have both thermodynamic and kinetic effects on intermetallic reactions in dissimilar joints. In this study, care was taken to measure the maximum interface temperature as reliably as possible. Thin $(0.5-\mathrm{mm})$ thermal couples were accurately pre-placed in a tight fitting groove machined in the surface of the Al sheet at the joint interface with the tip located under the center of the sleeve plunge area, where the highest temperatures are experienced. The measurements were repeated several times with good repeatability $\left[\mp 3 \mathrm{~K}\left(-270{ }^{\circ} \mathrm{C}\right)\right]$ and only the average from the highest three readings recorded. Typical temperature profiles recorded from the two dissimilar weld combinations are shown in Figure 10. Both temperature histories exhibit an initial steep heating rate, when the sleeve plunges, followed by a drop and inflection as the sleeve withdraws and the pin pushes back the expelled material. ${ }^{[24,43]}$ There is then a slower cooling rate stage after the tool withdraws. Overall, it can be seen that the weld thermal cycle was completed in under two seconds, although the tool workpiece contact only lasted one second. Despite the similar appearance of the profiles, it is notable that the clad $\mathrm{Al}(\mathrm{Si})-\mathrm{Mg}$ sample had a peak temperature nearly $30 \mathrm{~K}\left(-243{ }^{\circ} \mathrm{C}\right)$ lower than that of the baseline $\mathrm{Al}-\mathrm{Mg}$ welds.

It is interesting that the peak temperatures measured coincide with significant liquation reaction temperatures in the $\mathrm{Al}-\mathrm{Mg} / \mathrm{Si}$ alloy systems. In both joints, the interfacial reactions throughout the weld zone predominantly occurred in the solid state, as can be seen from Figure 7. However, some local melting was observed at the extreme edge of the weld nugget (such as at site E and D in Figure 6) where the highest temperature rise is expected. ${ }^{[7,24,43,48]}$ The temperature for the eutectic reaction $(\mathrm{Mg})+\gamma \rightarrow \mathrm{L}$ occurs at approximately $709 \mathrm{~K} \quad\left(436^{\circ} \mathrm{C}\right)$ by thermodynamic calculation (Figure 1(b)). This is just above the peak temperature measured in the clad $\mathrm{Al}(\mathrm{Si})-\mathrm{Mg}$ sample $\left[698 \mathrm{~K}\left(425^{\circ} \mathrm{C}\right)\right.$ Figure 10], but must have been exceeded locally as small solidified areas containing a eutectic mixture of $\mathrm{Al}_{12} \mathrm{Mg}_{17}$ and $\mathrm{Mg}$ can be observed on the $\mathrm{Mg}$ side of the joint (Figures 11(c) and (d)). This suggests that eutectic liquation between $\mathrm{Al}_{12} \mathrm{Mg}_{17}$ and $\mathrm{Mg}$ restricted the peak temperature rise in this weld.

In contrast, in the Al-Mg baseline sample, although the $\mathrm{Al}_{3} \mathrm{Mg}_{2}$ phase was also found to have melted locally under the tool shoulder during welding, it exhibited a different solidification behavior with a $\beta$ phase dendritic structure found growing within the $\gamma$ phase at the Al interface (Figures 11(a) and (b)). Comparison with the phase diagram in Figure 1(a) suggests that a local temperature of at least $723 \mathrm{~K}\left(450{ }^{\circ} \mathrm{C}\right)$ would be needed in order to produce this microstructure. This again agrees well with the average peak interface temperature measured under the shoulder in these joints, which was $725 \mathrm{~K}\left(452^{\circ} \mathrm{C}\right)$.

Both the thermal measurements and the microstructural observations thus indicate that the Al-Si coating led to a noticeable reduction in weld temperature, which was beneficial in controlling the intermetallic reaction rate across the joint interface. Why a higher peak temperature was reached in the unclad sample, despite liquation being expected to limit heat generation and being possible in both welds at a similar minimum temperature, is still unclear. However, a possible explanation is that the contact conditions would be different between the softer cladding material and the $\mathrm{Mg}$ sheet. In addition, the cladding alloy would have a lower flow stress and rate of flow stress change with temperature, compared to the stronger 6000 series alloy. This could have led to less overall power being dissipated, or a more uniform distribution of energy across the joint interface.

\section{F. Weld Mechanical Properties}

For experimental convenience, an Al-Si clad commercial 6016 sheet was employed to test the concept of using an Al-Si coating to control the detrimental interfacial reactions that are normally found in dissimilar Al-Mg welds. The results obtained for the clad material have, however, been compared to baseline welds prepared with a more common 6111 alloy. Although both alloys belong to the 6xxx series, their mechanical properties are slightly different and the $100 \mu \mathrm{m}$ Al-Si cladding made up a significant proportion of the $1 \mathrm{~mm}$ thickness of the 6016 sheet. In order to evaluate the effect of the Al-Si coating on the mechanical performance of the welds, it was therefore important to first assess the tensile behavior of the substrate materials. Table IV summarizes the tensile properties of the $\mathrm{Al}(\mathrm{Si})$ clad 6016 and 6111 sheet alloys used in this study, with data for the AZ31 Mg alloy for reference purposes. It can be seen that in comparison to 6111 , the $\mathrm{Al}(\mathrm{Si})$ clad sheet exhibited better ductility, while its yield strength was $\sim 25$ pct lower than for 6111 .

In Figure 12(a), lap shear test results for the $\mathrm{Al}(\mathrm{Si})-\mathrm{Mg}$ and $\mathrm{Al}-\mathrm{Mg}$ dissimilar joints are compared to those for $\mathrm{Mg}-\mathrm{Mg}$ similar joints prepared under identical conditions. Although the Al(Si) clad 6016 sheet had a lower yield stress, the Al-Si coating still led to a marked increase (about 20 pct higher) in the weld's average peak failure load, compared to that of the 

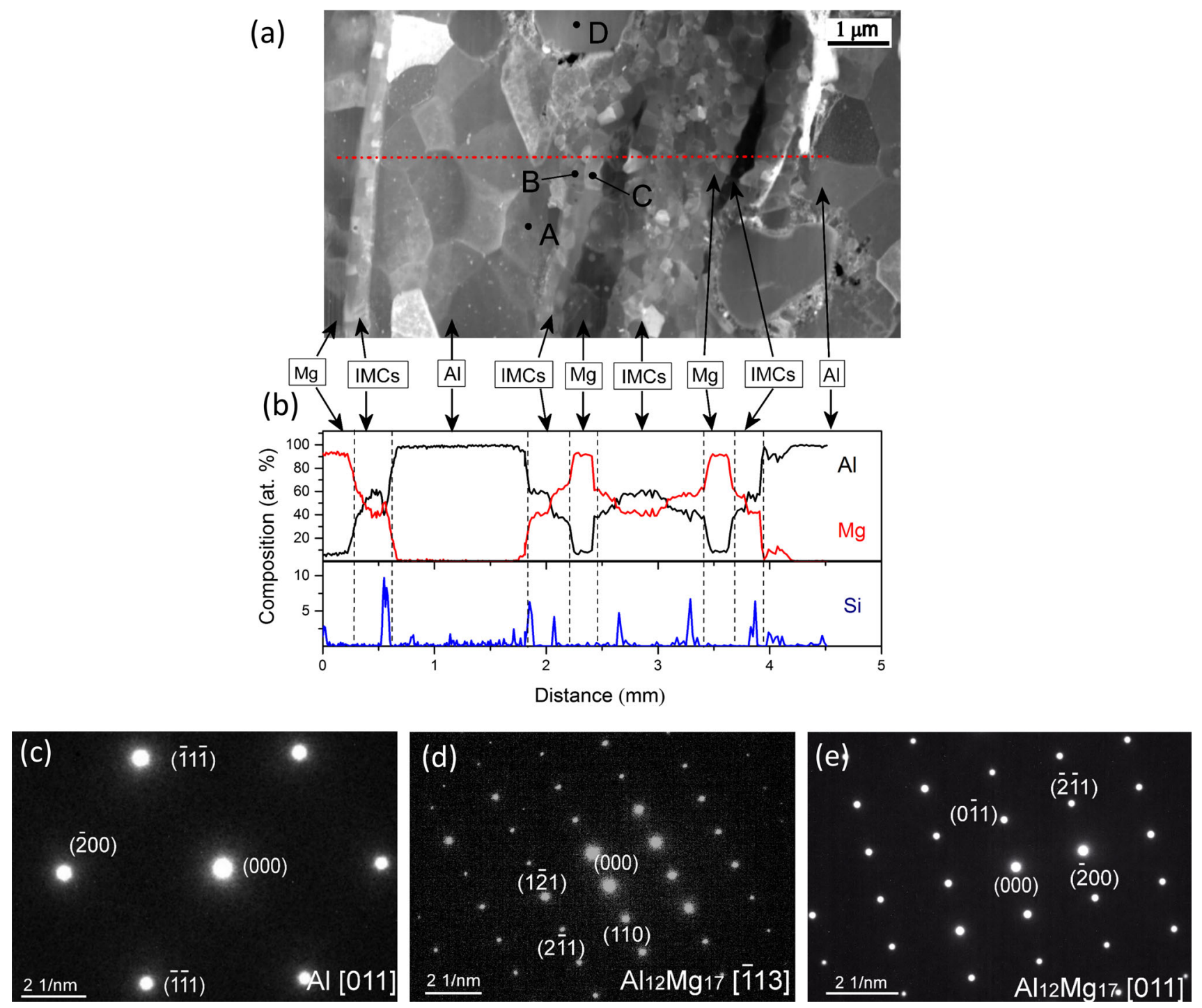

Fig. 8-TEM characterization of the intercalated interfacial region seen under the tool sleeve in the stir zone (site D in Fig. 6(b)) in the clad $\mathrm{Al}(\mathrm{Si})-\mathrm{Mg}$ weld: (a) STEM image showing the area of interest; (b) EDX line scan profile along the dashed line in (a) and ( $c$ through $e$ ) indexed selected area diffraction patterns from positions A-C in (a).

unclad $6111-\mathrm{Mg}$ welds. Encouragingly, this joint strength was nearly the same as that (97 pct) of the $\mathrm{Mg}-\mathrm{Mg}$ similar welds, shown for comparison purposes. In addition, comparison of typical loading curves from lap shear tests for the dissimilar joints in (Figure 12(b)) shows that the $\mathrm{Al}(\mathrm{Si})-\mathrm{Mg}$ welds also had a higher failure energy, with the area under the stress-strain curve being $\sim 30$ pct larger than for the unclad $\mathrm{Al}-\mathrm{Mg}$ baseline weld.

As well as correlating to a thinner IMC reaction layer, the enhanced mechanical performance of the dissimilar joints made with the coated $\mathrm{Al}(\mathrm{Si})$ sheet was also found to be associated with a change in fracture behavior. As illustrated in Figures 13(a) and (b), in both the coated and uncoated dissimilar joints interface failure occurred during the lap shear tests, indicating that in each case their mechanical performance was still adversely affected by intermetallic reaction. However, in the $\mathrm{Al}-\mathrm{Mg}$ baseline samples, cracks propagated within the intermetallic layer in a highly brittle fashion, with a planar path parallel to the interface with little crack bifurcation and few ligaments observed (Figure 13(a)). A similar crack propagation behavior has been reported by other researchers and leads to the poor joint performance generally reported for $\mathrm{Al}-\mathrm{Mg}$ dissimilar welds. ${ }^{[3-9]}$ In contrast, in the $\mathrm{Al}(\mathrm{Si})$ clad samples, cracks were found to be deflected by the Si particles embedded in the thinner IMC reaction layers (Figure 13(b)). Therefore, in addition to the reduced IMC layer thickness seen in the clad dissimilar welds, a more complex mix-mode failure also contributed to their higher fracture energy and improved joint efficiency.

\section{G. The Effectiveness of the Al-Si Coating in Improving Joint Properties During FSSW}

In this study a major reason for introducing a Si-rich clad layer in dissimilar welding of $\mathrm{Al}$ and $\mathrm{Mg}$ was to try 

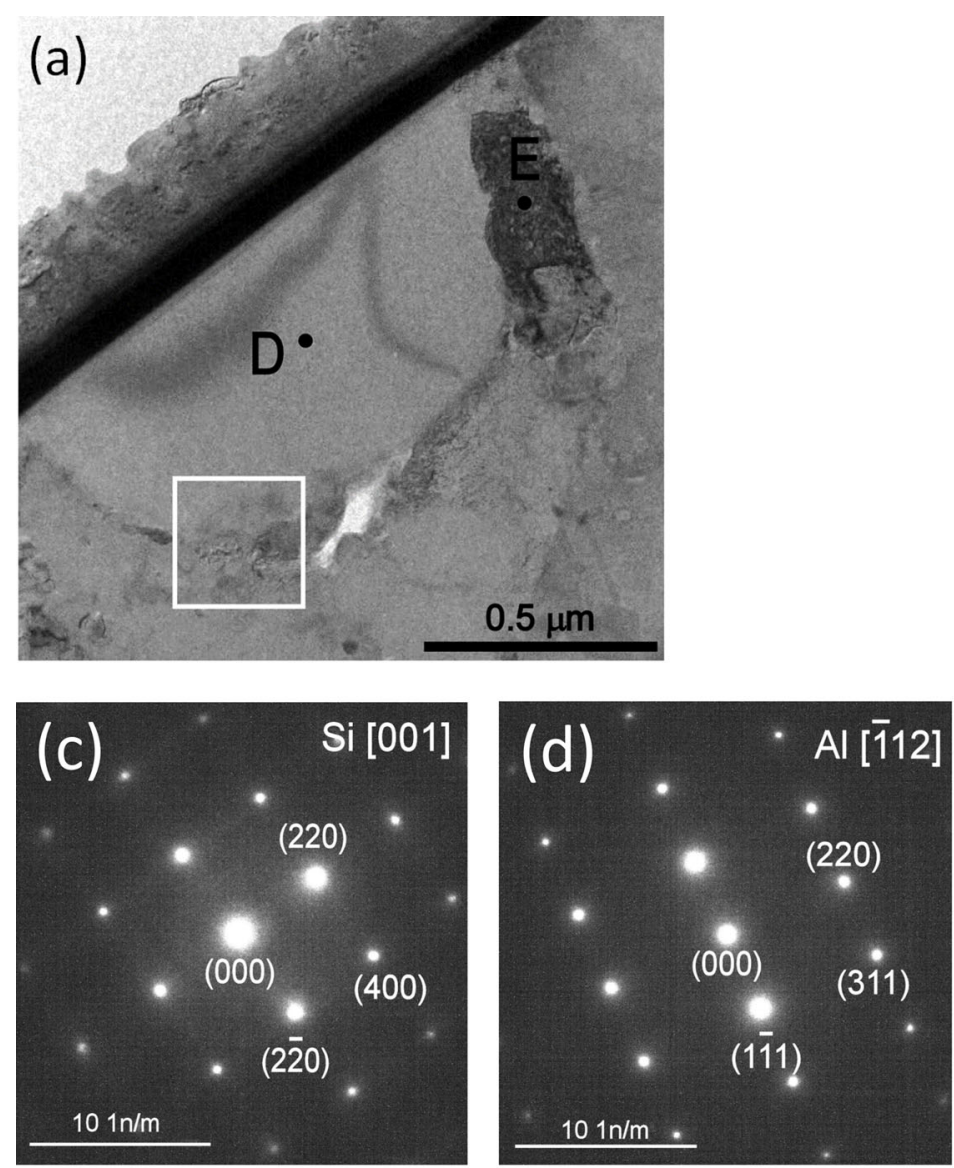
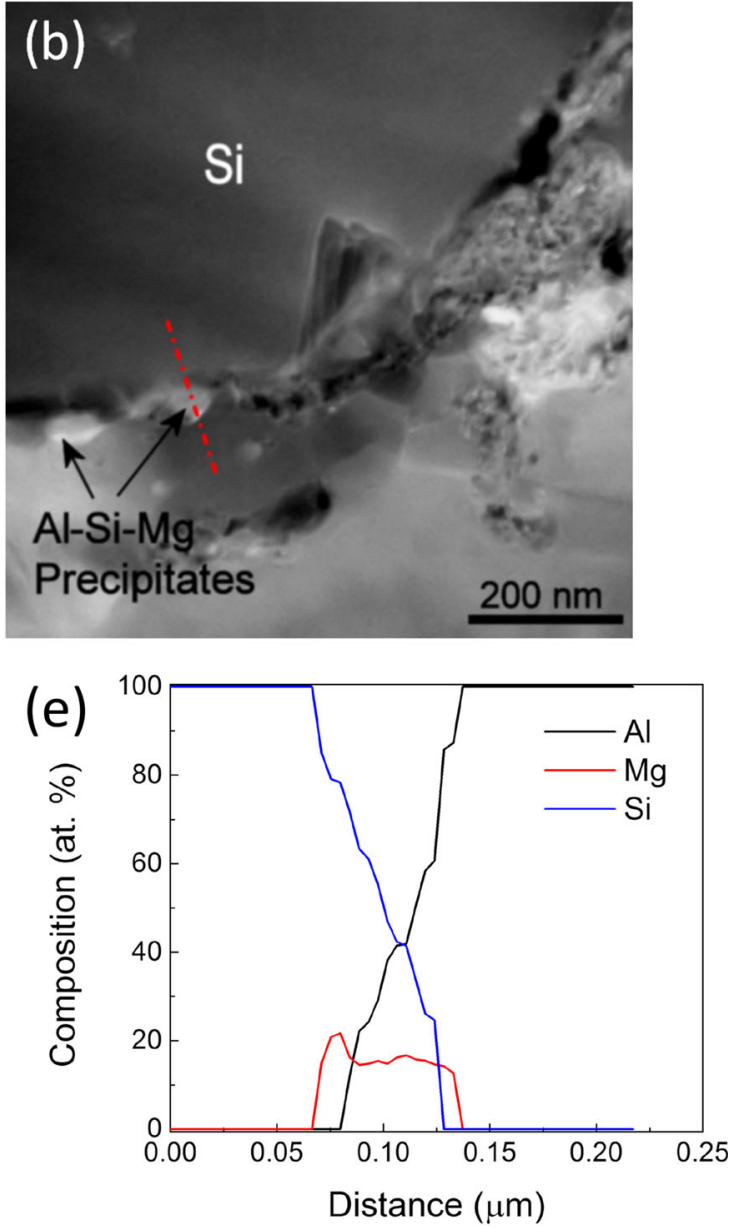

Fig. 9- (a) TEM image of the Si particle marked $\mathrm{D}$ in Fig. 8(a), from the reaction layer in the $\mathrm{Al}(\mathrm{Si})-\mathrm{Mg}$ weld; $(b)$ enlarged micrograph of the white box interface area in (a); (c) and $(d)$ indexed selected area diffraction patterns from positions D and E in (a); and (e) EDX line scan profile along the line in (b).

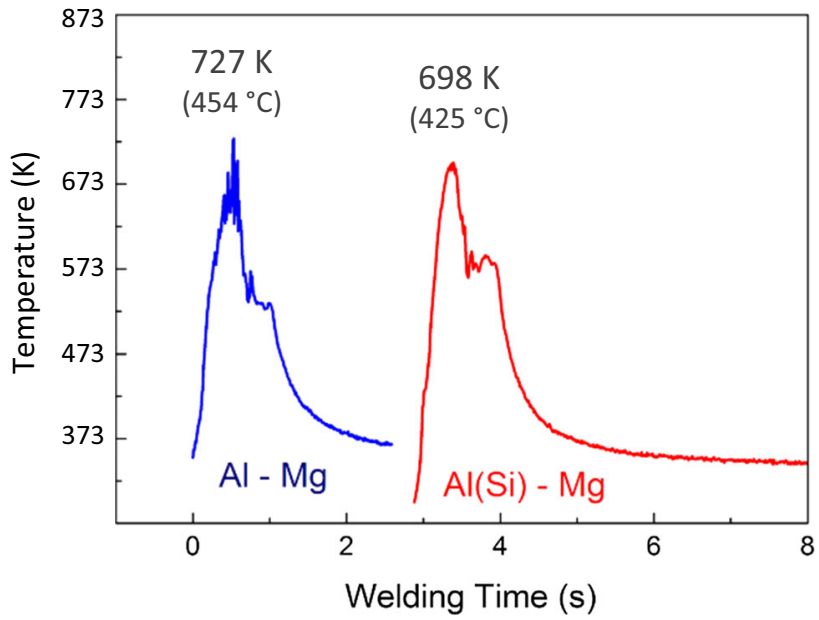

Fig. 10-Typical thermal histories of the $\mathrm{Al}(\mathrm{Si})-\mathrm{Mg}$ and $\mathrm{Al}-\mathrm{Mg}$ welds measured under the tool sleeve at the weld interface during FSSW.

to change the reaction path to promote preferential formation of the $\mathrm{Mg}_{2} \mathrm{Si}$ phase. Although the $\mathrm{Mg}_{2} \mathrm{Si}$ phase was synthesized in static heat treated samples, it was found to be absent in the Refill welds in any significant volume fraction, which compromised the efficacy of the coating, in terms of its ability for interfacial reaction control. This result is not totally surprising, given the very limited time available for diffusion, with a weld duration of only 1 second, and that nearly all the $\mathrm{Si}$ was held in relatively coarse-dispersed particles 2 to 3 microns in diameter. Hence, under transient welding conditions, there was not sufficient time for Si to react as significantly with the $\mathrm{Mg}$ in the matrix. However, when considered overall, the results are encouraging and suggest that if a coating could be developed with much finer nano-scale $\mathrm{Si}$ precipitates (e.g., by rapid solidification) it could be more effective in a welding situation.

In spite of the $\mathrm{Si}$ particles not reacting with $\mathrm{Mg}$ sufficiently rapidly during a rapid thermal cycle to directly influence the interfacial IMC reaction process, the Al-Si coating still proved successful in reducing the thickness of the IMC reaction layer formed at the weld interface. However, this was found to be linked to a reduction in the peak weld temperature by $30 \mathrm{~K}$ $\left(-243{ }^{\circ} \mathrm{C}\right)$, which retarded the growth of the Al-Mg IMCs. In addition, the softer surface of the coated 


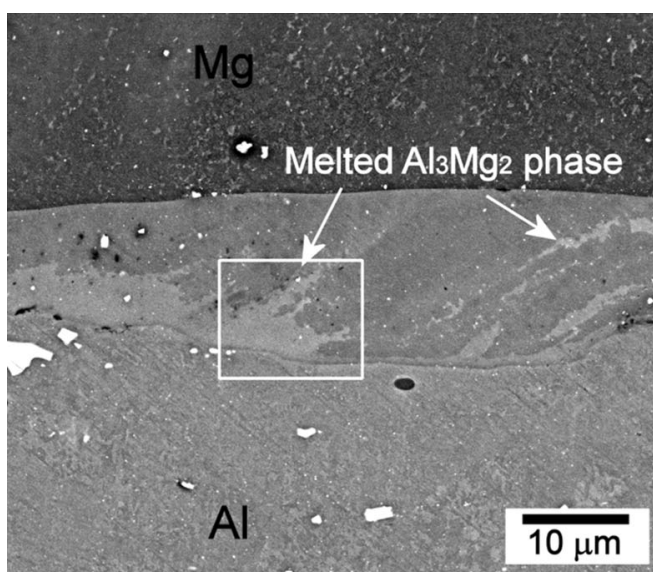

(a)

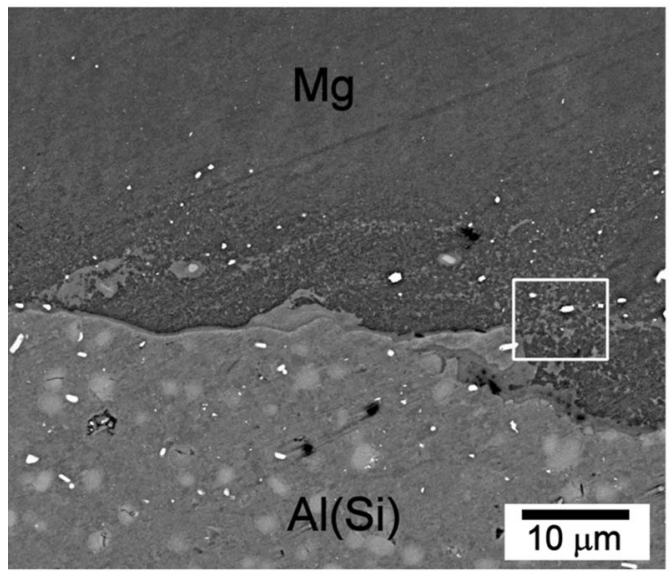

(c)

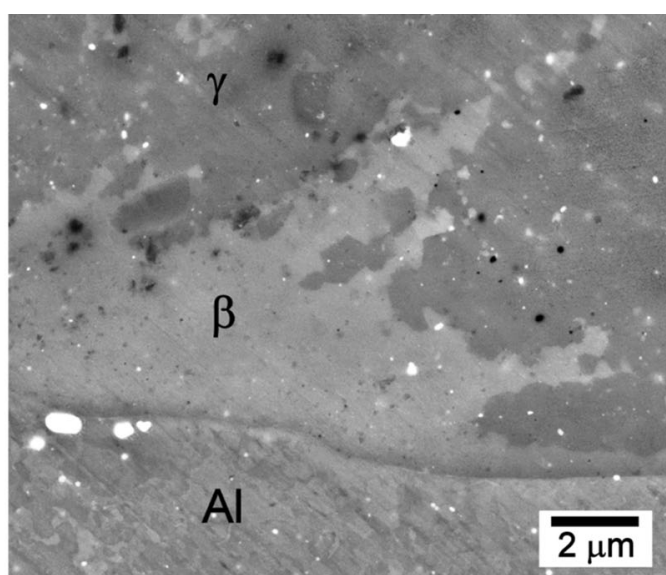

(b)

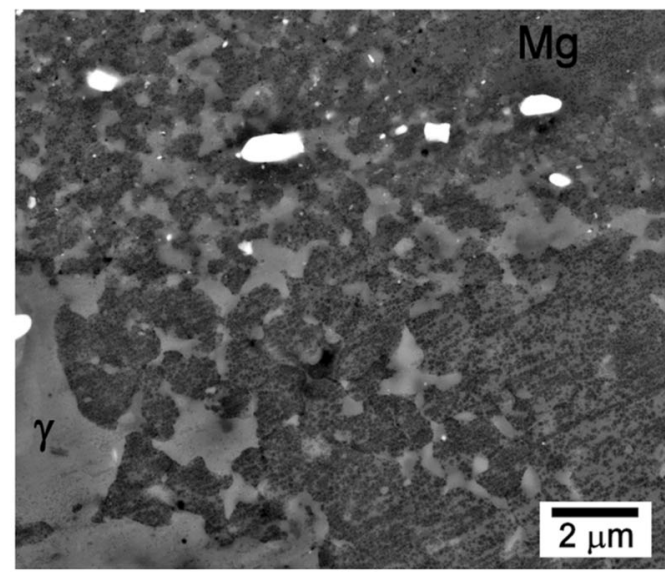

(d)

Fig. 11-SEM-BSE images taken at site E in Fig. 6, showing the locally melted and re-solidified microstructures found at the edge of the weld zone: (a) the microstructure of the melted $\mathrm{Al}_{3} \mathrm{Mg}_{2}$ phase in the unclad Al-Mg welds; $(b)$ an enlarged micrograph from the white box area in (a); (c) the eutectic morphology in the $\mathrm{Al}(\mathrm{Si})-\mathrm{Mg}$ welds; $(d)$ enlarged micrograph of the white box area in $(c)$.

Table IV. Summary of the Tensile Properties Measured for the Clad (Al(Si)), AA6111, and AZ31 Sheet Alloys

\begin{tabular}{lccc}
\hline Material & Yield Strength $(0.2 \mathrm{pct})(\mathrm{MPa})$ & Tensile Strength $(\mathrm{MPa})$ & Fracture Strain \\
\hline $\mathrm{Al}(\mathrm{Si})$ & 129 & 231 & 0.27 \\
Al6111 & 174 & 311 & 0.22 \\
AZ31 & 201 & 275 & 0.18 \\
\hline
\end{tabular}

aluminum sheet caused the IMC particles to be more redistributed by greater material flow during weld formation. Thus, a softer coating may also be an advantage in terms of achieving better bonding in the FSSW process. When welding dissimilar metals, after complete bonding is achieved, the joint fracture energy typically rapidly reduces with increasing thickness of any IMC reaction layer at the interface. ${ }^{[3]}$ Therefore, the increase in strength and fracture energy seen for the dissimilar welds produced with the Al-(Si) clad sheet can be attributed to the combined effects of the coating reducing the thickness of the $\mathrm{Al}-\mathrm{Mg}$ intermetallic reaction layer, together with more material interface mixing and the presence of Si particles within the IMC phase toughening the interfacial layer.

\section{CONCLUSIONS}

Following an initial thermodynamic assessment, an Al-Si alloy was identified as a promising coating material that could potentially change the reaction path and reduce the detrimental effects of IMC reactions normally seen in Al-Mg dissimilar welds. Under both static annealing and welding conditions, the Al-Si coating investigated was shown to be successful in improving the performance of the dissimilar joints, by reducing the IMC layer thickness.

Thermodynamic calculations indicated that, with an Al-Si coating alloy, the $\mathrm{Mg}_{2} \mathrm{Si}$ phase will be preferentially synthesized in an $\mathrm{Al}-\mathrm{Mg}$ diffusion couple and substitute for the undesirable binary $\mathrm{Al}-\mathrm{Mg}$ phases. 


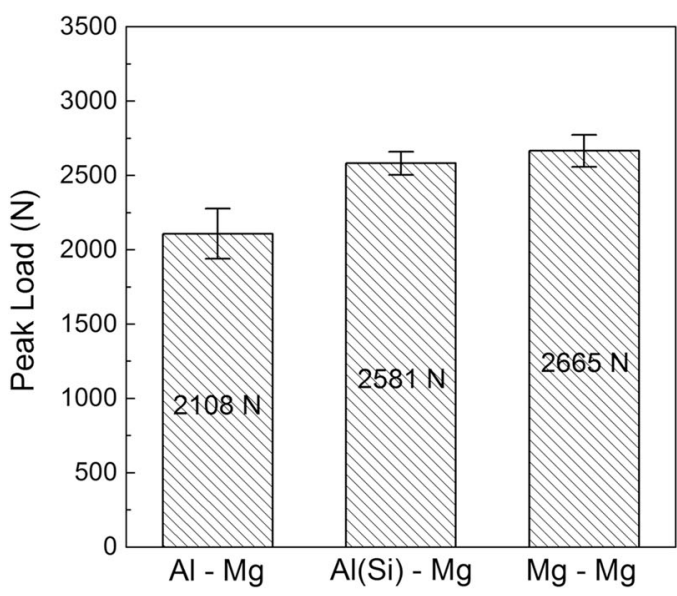

(a)

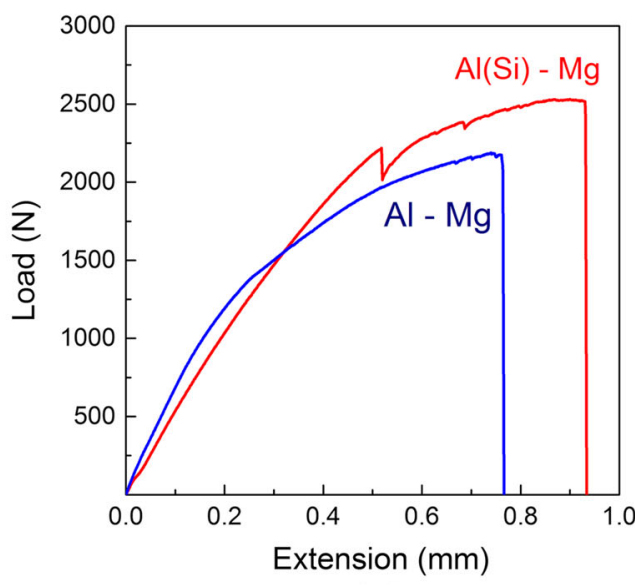

(b)

Fig. 12-Comparison of $(a)$ lap shear strengths and $(b)$ typical load-extension curves of the $\mathrm{Al}(\mathrm{Si})-\mathrm{Mg}$ and $\mathrm{Al}-\mathrm{Mg}$ FSSW welds. The joint strength of an $\mathrm{Mg}-\mathrm{Mg}$ similar weld is also provided in (a) for comparison purposes.

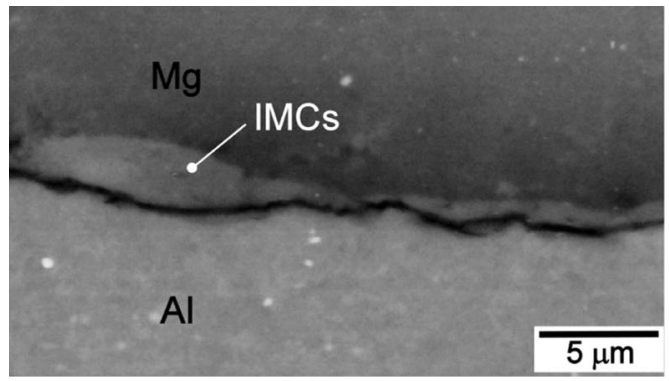

(a)

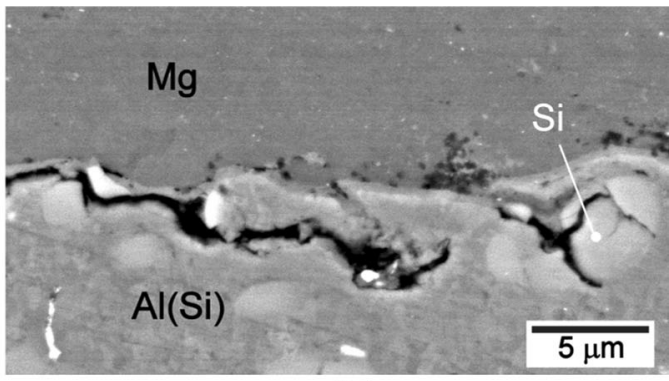

(b)

Fig. 13-Examples of crack propagation in the interfacial regions of (a) the $\mathrm{Al}-\mathrm{Mg}$ baseline and $(b)$ the $\mathrm{Al}(\mathrm{Si})-\mathrm{Mg}$ dissimilar welds.

Long-term isothermal static annealing experiments confirmed that the $\mathrm{Mg}_{2} \mathrm{Si}$ phase formed at the $\mathrm{Al}-\mathrm{Mg}$ joint interface and reduced the thickening rate of the faster growing $\beta$-phase. As a result, the entire IMC layer thickness was reduced by $\sim 50$ pct. However, when welded with the Refill ${ }^{\mathrm{TM}}$ FSSW process, $\mathrm{Mg}_{2} \mathrm{Si}$ was not detected in any significant volume as the very short weld duration (less than 1 second) and the relatively large size of the Si particles compromised the efficacy of the coating material under rapid welding conditions.

Despite not behaving as intended, the softer $\mathrm{Al}(\mathrm{Si})$ cladding layer still significantly reduced the IMC thicknesses during welding due to its indirect effect on reducing the peak weld temperature. In addition, when the coating was applied, the fracture energy of the Al-Mg dissimilar welds was significantly increased and their lap shear strength improved to as high as $97 \mathrm{pct}$ of the $\mathrm{Mg}-\mathrm{Mg}$, similar, baseline welds. This substantial improvement was shown to be caused, not just by a reduction in the IMC layer thickness, but also from the more intercalated interface and Si particles incorporated into the IMC reaction layer toughening the interface reaction layer.

Finally, the results suggest that it would be desirable to obtain a coating material containing Si precipitates of a much smaller size, so that the capability demonstrated in the static heat treatments for controlling $\mathrm{Al}-\mathrm{Mg}$ interfacial reactions could be fully realized during a more rapid welding process.

\section{ACKNOWLEDGMENTS}

The authors would like to thank Dr. Octav Ciuca for assistance with electron microscopy and the EPSRC program grant LATEST2 (EP/G022402/1) for funding this research.

\section{OPEN ACCESS}

This article is distributed under the terms of the Creative Commons Attribution 4.0 International License (http://creativecommons.org/licenses/by/4.0/), which permits use, duplication, adaptation, distribution and reproduction in any medium or format, as long as you give appropriate credit to the original author(s) and the source, provide a link to the Creative Commons license and indicate if changes were made. 


\section{REFERENCES}

1. A. Jambor and M. Beyer: Mater. Des., 1997, vol. 18, pp. 203-09.

2. J. Hirsh: Metall. Mater. Trans. A, 2011, vol. 52A, pp. 81824

3. A. Simar and M.-N. Avettand-Fènoël: Sci. Technol. Weld. Join., 2017, vol. 22, pp. 389-403.

4. A. Panteli, J.D. Robson, I. Brough, and P.B. Prangnell: Mater. Sci. Eng. A, 2012, vol. 556, pp. 31-42.

5. A.A. Mclean, G.L.F. Powell, I.H. Brown, and V.M. Linton: Sci. Technol. Weld. Join., 2003, vol. 8, pp. 462-64.

6. U. Suhuddin, V. Fischer, F. Kroeff, and J.F. dos Santos: Mater. Sci. Eng., 2014, vol. 590, pp. 384-89.

7. Z. Liang, G. Qin, H. Ma, F. Yang, and Z. Ao: Sci. Technol. Weld. Join., 2017, vol. 22, pp. 363-72.

8. H.M. Rao, J.B. Jordon, B. Ghaffari, X. Sub, A.K. Khosrovaneh, M.E. Barkey, W. Yuan, and M. Guo: Int. J. Fatigue, 2016, vol. 82, pp. 737-47.

9. Y. Wang, and P.B. Prangnell: Mater. Charact., 2017, in press.

10. D. Dietrich, D. Nickel, M. Krause, T. Lampke, M.P. Coleman, and V. Randle: J. Mater. Sci., 2011, vol. 46, pp. 357-64.

11. E.M. Tanguep Njiokep, M. Salamon, and H. Mehrer: Defect Diffus. Forum, 2001, vols. 194-199, pp. 1581-86.

12. L. Wang, Y. Wang, P.B. Prangnell, and J.D. Robson: Mater. Trans. A, 2015, vol. 46A, pp. 4106-14.

13. S. Sampson: Acta Cryst., 1965, vol. 19, pp. 401-12.

14. D.S. D'Antuono, M.L. Taheri, J. Gaies, and W. Golumbfskie: Microsc. Microanal., 2012, vol. 18, pp. 1792-93.

15. A. Panteli, J.D. Robson, Y.-C. Chen, and P.B. Prangnell: Metall. Mater. Trans. A, 2013, vol. 44A, pp. 5773-81.

16. H. Zhang and J. Song: Mater. Lett., 2011, vol. 65, pp. 3292-94.

17. L. Liu, L. Zhao, and R. Xu: Mater. Des., 2009, vol. 30, pp. 4548-51.

18. H. Zhang, L. Li, Y. Chen, A.A. Luo, and L. Liu: Int. J. Cast Met. Res., 2016, vol. 29, pp. 338-43.

19. M. Sun, S.T. Nikneja, H. Gao, L. Wu, and Y. Zhou: Mater. Des., 2016, vol. 91, pp. 331-39.

20. Y. Tang, Y. Du, L. Zhang, X. Yuan, and G. Kaptay: Thermochim. Acta, 2012, vol. 527, pp. 131-42.

21. C. Schilling, and J.D. Santos: US6722556 B2, 2004.

22. R.B. Wagstaff, D.J. Lloyd, and T.F. Bischoff: Mater. Sci. Forum, 2006, vols. 519-521, pp. 1809-14.

23. B.M. Al-Zubaidy, Y-C. Chen, and P.B. Prangnell: Assessment of rapid refill FSSW for 6111-T4 aluminium automotive alloys, 14th Int. Frict. Stir Weld. Symp., Beijing, China, TWI. 2014.

24. B.M. Al-Zubaidy: Material interactions in a novel refill friction stir spot welding approach to joining $\mathrm{Al}-\mathrm{Al}$ and $\mathrm{Al}-\mathrm{Mg}$ automotive sheets. Ph.D. Thesis, The University of Manchester, Manchester, UK, 2017, pp. 216-39.
25. J.L. Murray and A.J. McAlister: Bull. Alloy Phase Diag., 1984, vol. 5 , pp. $74-84$

26. K. Nakamura and M. Kamoshida: J. Appl. Phys., 1997, vol. 48, pp. 5349-51.

27. D. Bradai, M. Kadi-Hanifi, P. Zieba, W. Kuschke, and W. Gust: J. Mater. Sci., 1999, vol. 34, pp. 5331-36.

28. J. Zhang, Z. Fan, Y. Wang, and B. Zhou: J. Mater. Sci. Lett., 1999, vol. 18 , pp. $783-84$.

29. M. Feuerbach, C. Thomas, J. Makongo, and S. Hoffmann: Cryst. Mater., 2007, vol. 222, pp. 259-88.

30. A. Zolriasatein, R.A. Khosroshahi, M. Emamy, and N. Nemati: Int. J. Miner. Met. Mater., 2013, vol. 20, pp. 290-97.

31. Y. Wang, G.-Q. Luo, L.-J. Li, Q. Shen, and L.-M. Zhang: $J$. Mater. Sci., 2014, vol. 49, pp. 7298-308.

32. S.Y. Betsofen, Y.R. Kolobov, E.F. Volkova, S.A. Bozhko, and I.I. Voskresenskaya: Russ. Metall., 2015, vol. 2015, pp. 257-63.

33. H. Zhang, S.L. Shang, Y. Wang, A. Saengdeejing, L.Q. Chen, and Z.K. Liu: Acta Mater., 2010, vol. 58, pp. 4012-18.

34. A. Zolriasatein and A. Shokuhfar: Mater. Des., 2015, vol. 75, pp. 17-23.

35. P. Venkateswaran, Z.-H. Xu, X.-D. Li, and A.P. Reynolds: $J$. Mater. Sci., 2009, vol. 44, pp. 4140-47.

36. G.-H. Li, H.S. Gill, and R.A. Varin: Metall. Metall. Trans. A, 1993, vol. 24A, pp. 2383-91.

37. L. Lu, M.Q. Lai, and M.L. Hoe: Nanostruct. Mater., 1998, vol. 10, pp. 551-63.

38. Y.-Z. Lu, Q.-D. Wang, X.-Q. Zeng, W.-J. Ding, and Y.-P. Zhu: $J$. Mater. Sci. Lett., 2001, vol. 20, pp. 397-99.

39. V. Milekhine, M.I. Onsøien, J.K. Solberg, and T. Skaland: Intermetallics, 2002, vol. 10, pp. 743-50.

40. J. Tani and H. Kido: Comput. Mater. Sci., 2008, vol. 42, pp. $531-36$.

41. G. Frommeyer, S. Beer, and K.V. Oldenburg: Z. Metallkd., 1994, vol. 85 , pp. $372-77$.

42. D. Kevorkov, R. Schmid-Fetzer, and F. Zhang: J. Phase Equilib. Diff., 2004, vol. 25, pp. 140-51.

43. U.F.H. Suhuddin, V. Fischer, and J.F. dos Santos: Scr. Mater., 2013, vol. 68, pp. 87-90.

44. A. Reilly, H.R. Shercliff, Y.-C. Chen, and P.B. Prangnell: $J$. Mater. Proc. Technol., 2015, vol. 225, pp. 473-84.

45. U.F.H. Suhuddin, V. Fischer, F. Kroeff, and H.F.D. Santos: Mater. Sci. Eng. A, 2014, vol. 590, pp. 384-89.

46. M. Murayama and K. Hono: Acta Mater., 1999, vol. 47, pp. $1537-48$.

47. C. Ravi and C. Wolverton: Acta Mater., 2004, vol. 52, pp. 4213-27.

48. P. Jedrasiak, H.R. Shercliff, A. Reilly, G.J. McShane, Y.C. Chen, L. Wang, J.D. Robson, and P.B. Prangnell: J. Materials Eng. Perform., 2017, vol. 25, pp. 4089-98. 